\title{
Green Synthesis: An Eco-friendly Route for the Synthesis of Iron Oxide Nanoparticles
}

\author{
Priya $^{\dagger}$, Naveen $^{\dagger}$, Kamaljit Kaur and Amanpreet K. Sidhu *t \\ Department of Biotechnology, Khalsa College, Amritsar, India
}

\section{OPEN ACCESS}

Edited by:

Mubarakali Davoodbasha,

B. S. Abdur Rahman Crescent Institute Of Science And Technology,

India

Reviewed by:

Yannan Yang,

The University of Queensland, Australia

Yong Chen,

University of South China, China Vijayakumar Sekar,

Shandong University, China

*Correspondence:

Amanpreet K. Sidhu aman.preet1807@gmail.com

${ }^{\dagger}$ These authors have contributed equally to this work and share first authorship

Specialty section:

This article was submitted to Nanomaterials,

a section of the journal

Frontiers in Nanotechnology

Received: 18 January 2021 Accepted: 31 May 2021

Published: 15 June 2021

Citation:

Priya, Naveen, Kaur K and Sidhu AK (2021) Green Synthesis: An Ecofriendly Route for the Synthesis of Iron

Oxide Nanoparticles.

Front. Nanotechnol. 3:655062. doi: 10.3389/fnano.2021.655062
Green approach has received major attention for the synthesis of metal oxide nanoparticles. One such metal oxide nanoparticles are iron oxide nanoparticles (IONPS). IONPs have fetched a great deal of interest in recent era because of their magnetic nature, as they can be easily recovered from the reaction mixture by applying an external magnetic field. Although, a variety of chemical and physical methods of synthesis are known, green synthesis is safer, sustainable and biologically acceptable. Plants and microbes are the main biological materials used for the green synthesis. In present review, the synthesis of IONPs by using plants, bacteria, fungi and algae have been highlighted. IONPs produced by plants, fungi, bacteria and algae usually falls in 1-100 nm range and are of distinct shapes like cubic, tetragonal crystalline, spherical, cylindrical, elliptical, octahedral, orthorhombic, hexagonal rods, nanosphere and quasi spherical. Furthermore, these biomaterials play role of reducing, capping, stabilizing and fabricating agents in green synthesis of nanoparticles. The review put forward a comprehensive report of various routes used for synthesizing IONP, biologically. Intuition into the procedures for synthesis of nanoparticles will help to nourish our learning in the area of nanotechnology.

Keywords: antimicrobial, biological synthesis, characterization, green approach, iron oxide, nanoparticles

\section{INTRODUCTION}

Nanotechnology is propitious and widely flourishing branch of science that has received major success in the era of modern technology. Nanoparticles are materials that shows uniqueness in size (generally varies from 1 to $100 \mathrm{~nm}$ ), structure, physio-chemical, electric, magnetic, thermal, mechanical, catalytic, optical scattering properties and shape (Chen et al., 2013; Rastar et al., 2013; Pantidos and Horsfall, 2014; Arya et al., 2019; Hussain et al., 2019; Saleh et al., 2019; Turan et al., 2019; Vasantharaj et al., 2019). Properties and reactivity of the nanoparticles is largely defined by their ultra-small size and large surface area (Campos et al., 2015; Srikar et al., 2016; Mourdikoudis et al., 2018). Nanoparticles are highly intriguing as they exist as transition between bulk matters and atomic or molecular structures. A bulk material has constant physical and chemical properties regardless of its size, but at the nano-level this scenario is often different. Several bulk materials have demonstrated astonishing features when studied at nano scale (Thakkar et al., 2010). As far as structure of the nanoparticles is concerned, a greet degree of complexity is observed. They consist of three layers i.e., the surface layer, the shell and the core. Each layer differs from other in functional groups like metal ions, surfactants, small molecules and polymers. Core is generally represented as the nanoparticles (Khan et al., 2019). The properties like size, shape, composition and structural framework are specific to nanoparticles and need to be optimized during the synthesis process (Revati et al., 2011). Based upon their distinct characteristics, NPs are categorized into different 


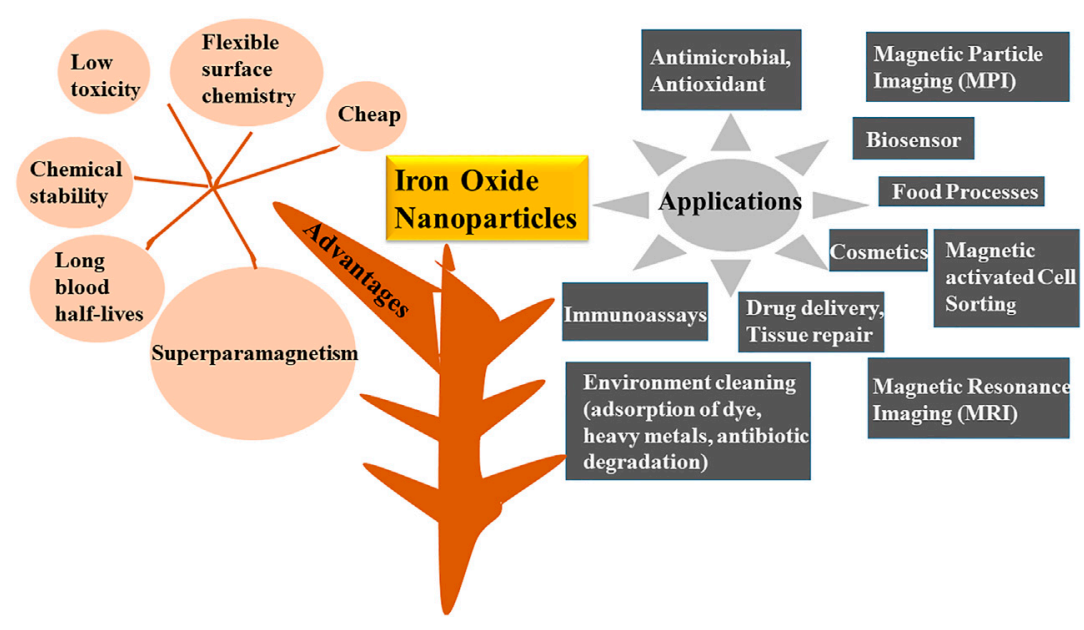

FIGURE 1 | Advantages and applications of Iron oxide nanoparticles.

classes including-carbon and lipid based, metal, ceramics, semiconductor and polymeric (Bhatia, 2016; Ealias and Saravanakumar, 2017; Amoabediny et al., 2018; Khan et al., 2019). Different metal oxides like iron oxide, nickel oxide, zinc oxide, copper oxide, silver oxide, titanium dioxide, tin oxide, tungsten (di, tri) oxide, magnesium oxide, silicon and gold oxides have broad applications in the environment (detection of toxins and pollutants, remediation, photo degradation, water treatment), catalysis, textile industry, electronics (batteries, optical limiting devices, gas sensor), mechanical industries, pharmaceutical sector (cancer therapy, drug delivery, tissue repair) and energy scavenging (nanogenerators) (Oskam, 2006; Laurent et al., 2008; Kulkarni and Muddapur, 2014; Kumar et al.,2018; Mei and Wu, 2018; Odularu, 2018; Aminabad et al., 2019; Khan et al., 2019; Khan et al., 2019; Malakootian et al., 2019; Massironi et al., 2019; Saleh et al., 2019; Shnoudeh et al., 2019; Vahed et al., 2019; Vasantharaj et al., 2019; Vinci and Rapa, 2019; Yusof et al., 2019; Borah et al., 2020; Hernández et al., 2020; Vahidi et al., 2020; Mughal et al., 2021). Out of these metal oxides nanoparticles, one of the preeminent biocompatible nanoparticles are iron oxides as they have magnificent minuscule physical characteristics like superparamagnetism, firmness in liquid solution, low suseptibility to oxidation, long blood half-lives, flexible surface chemistry with wide range of applications in environmental regulation like antibiotic degradation, adsorption of dyes, food related processes, biomedical (drug delivery, magnetic cell sorting, magnetic resonance imaging (MRI), magnetic particle imaging (MPI), immunoassays, tissue engineering, stem cell tracking, hyperthermia treatment of cancer), bioengineering, cosmetics and bio sensing along with antimicrobial activity against various pathogens like fungus, bacteria and ROS (Figure 1) (Khalil et al., 2017; Beheshtkhoo et al., 2018; Sruthi et al., 2019; Vasantharaj et al., 2019; Bhuiyan et al., 2020; Gao et al., 2020; Malhotra et al., 2020; Mondal et al., 2020; Sharma et al., 2021; Tong et al., 2021). Iron oxide nanoparticles (IONPs) also demonstrates typical core and shell structure. Owing to this core-

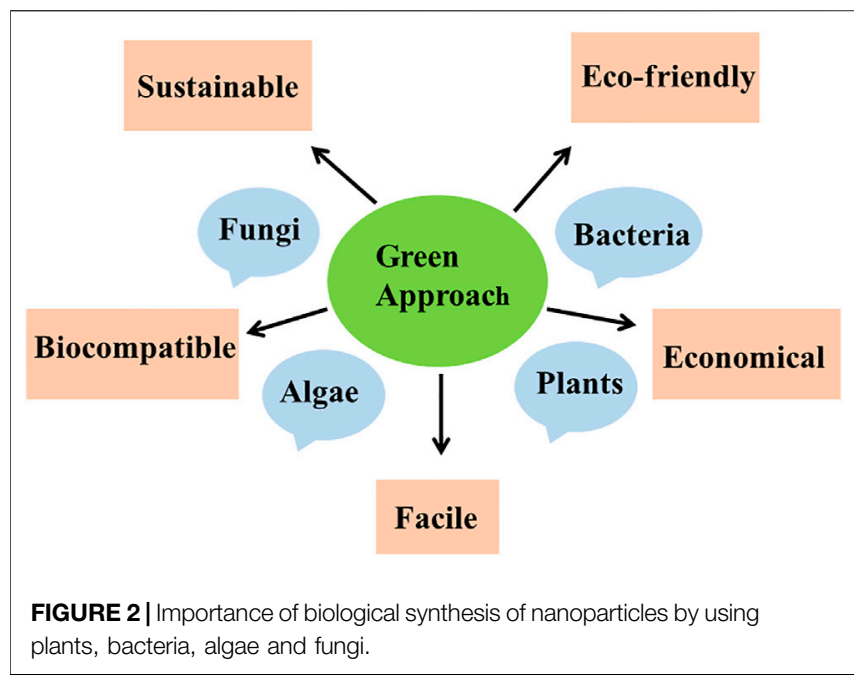

shell structure IONPs possess characteristics of both hydrous iron oxides and metallic iron (Li and Zhang, 2006). Recently, these are also defined as "Nanozyme" for their native enzyme like activities. They posess catalytic properties similar to various oxidases like peroxidases, catalase, sulfite oxidase and superoxide dismutase which could make them a new enzyme mimics (Zhang et al., 2019; Gao et al., 2020). One another astonishing feature of these particles is their potential to join together with different biological molecules like peptides, enzymes, nucleic acids, lipids, fatty acids and various metabolites. Molecules immobilized on the nanoparticles demonstrate superior properties and high reusuability over the unimmobilized counterpart (Singh et al., 2016; Jubran et al., 2020). Different chemical, physical and biological methods have been employed for the synthesis of IONPs. Chemical synthesis generally comprises of coprecipitation, micro-emulsion techniques, flow-injection, reverse micelles, sol-gel synthesis and hydrothermal reactions (Laurent et al., 2008; Wu et al., 2008). In these kinds of processes, 


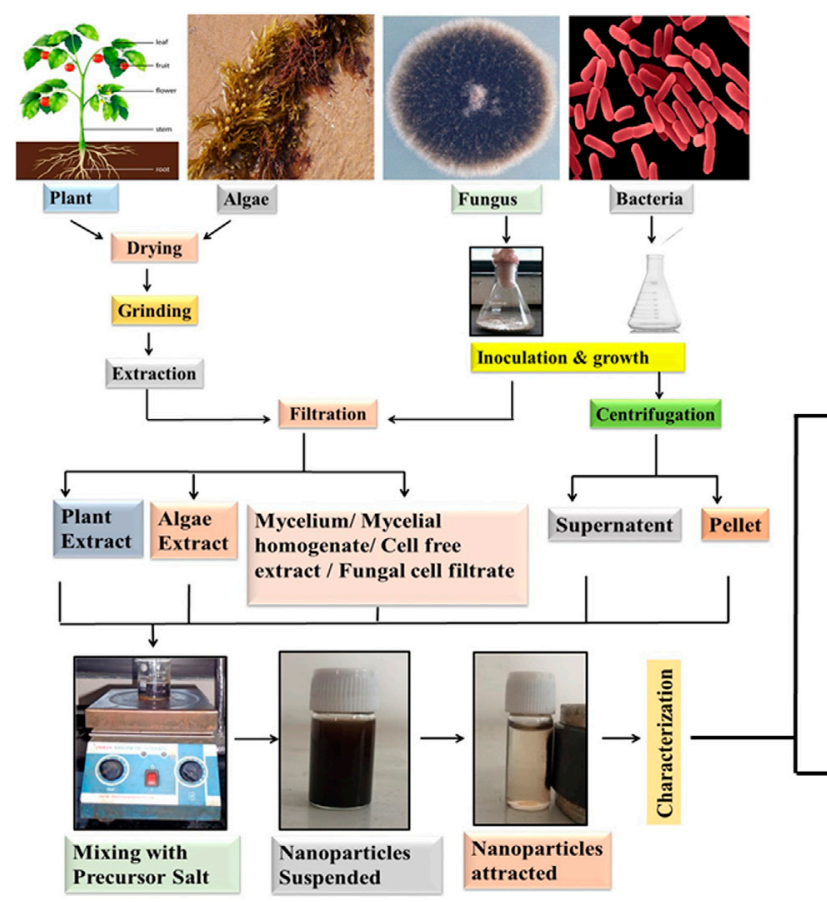

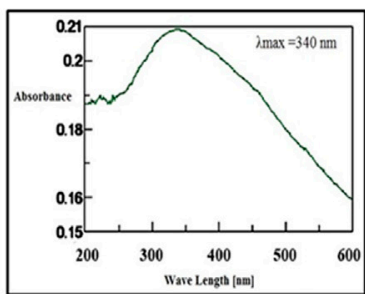

UV visible analysis

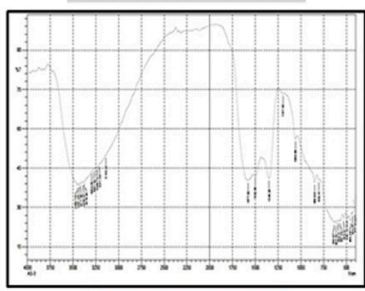

FT-IR analysis

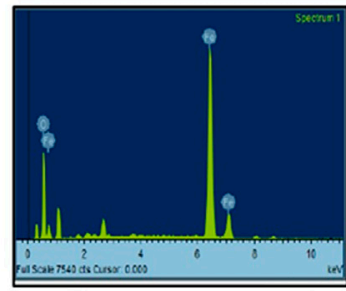

EDX analysis

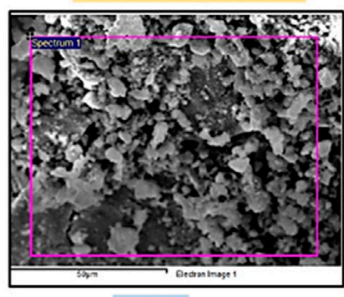

SEM

FIGURE 3 | General protocol for the biosynthesis of Iron oxide nanoparticles by using plants, algae, fungi and bacteria which includes drying, grinding and extraction of the biomaterial in the case of plants and algae whereas in case of bacteria and fungus initial steps include inoculation and growth. Extracted biomaterial is then filtered (plants, algae, fungus) and centrifuged (bacteria), followed by mixing with the precursor salt. At last the characterization of NPs is done by UV visible, FT-IR spectroscopy, EDX and SEM techniques.

particle dispersal, clumps and size equalization is the main obstacle. Besides, chemical based methods also includes the utilization of solvents like sodium borohydride, hydrazine, potassium bitartrate and sodium dodecyl sulfate, these all are harmful to the environment due to the generation of noxious waste flows. Furthermore, physical genesis includes milling, grinding and thermal ablation; all these methods are hourly costly due to the thorough energy requirement. Another big disadvantage of this approach is its extremely low output yield (Rauwel et al., 2015; Moghaddam et al., 2014; Khalil et al., 2017; Gahlawat and Choudhury, 2019; Borah et al., 2020). It has been cleared that there is a need to shift toward green, safer, biologically acceptable, stable, cost effective, fast and ecofriendly method of synthesis (Figure 2) (Salam et al., 2012; Senthilkumar and Sivakumar, 2014; Aziz et al., 2015; Adelere and Lateef, 2016; Ovais et al., 2016). Biological biosynthesis of iron oxide nanoparticles is based upon the usage of living biota like plants, bacteria, algae, actinomycetes, viruses and fungi (Thakkar et al., 2010; Schröfelet al., 2014; Vijayaraghavan and Ashokkumar, 2017; Mirza et al., 2018; Latif et al., 2019; Gahlawat and Choudhury, 2019; Sharma et al., 2019; Vasantharaj et al., 2019). This organic synthesis depends on the usage of universal solvent i.e., water and generates nanoparticles that are free from venomous chemical impurities and made them widely accepted in biomedical field (Pantidos and Horsfall, 2014; Gholampoor et al., 2015). Bioreduction and biosorption are the two basic steps followed by natural synthesis. Bioreduction is the process in which metal ions are reduced chemically into their stable forms and biosorption refers to the process of binding of metal ions on the surface of organism like cell wall, peptides to form more stabilized complexes (Pantidos and Horsfall, 2014). Moreover, biobased synthesis excludes subsidiary steps like capping or adhering of the biologically active compounds on their surface for producing stable particles. In addition, this type of synthesis processes are less time consuming as compared to physicochemical methods (Gahlawat and Choudhury, 2019). In this review we mainly emphasize on the biological synthesis of iron oxide nanoparticles by bacteria, fungi, algae and plants (Figure 3), along with their merits and demerits.

\section{BIOSYNTHESIS OF IRON OXIDE NANOPARTICLES USING PLANTS}

Plants are generally considered as freely available, easy to handle, harmless and cheap material for synthesis of various types of nanoparticles (Noruzi, 2015). The biosynthesis process utilized distinct parts like roots, leaves, seeds, flowers, fruits, peels, petals, whole plant and seed husk as these are rich in various biomolecules like carbohydrates, amino acids, flavonoids, proteins, saponins, terpenoids, nitrogenous compounds that function as a reducer, stabilizer, redox mediators and capping agents in the synthesis of nanoparticles (Mittal et al., 2013; Royand Das, 2015; Rajesh Kumar and Bharath et al., 2017; 
Mirza et al., 2018; Nadeem et al., 2018; Vasantharaj et al., 2019; Mondal et al., 2020). In current era, an extensive research is carried out on the synthesis of IONP by plants. One principal reason behind this can be the fact that bacteria and fungi demands lengthy incubations whereas phytochemicals present in plants are capable of reducing the metal ions in comparatively less time (Singh et al., 2018). Recent studies clarifies that plant extracts of Solanum trilobatum, Ziziphora tenuior, Persia Americana, Abutilon indicum, Azadirachta indica, Camellia sinensis and green tea leaves were utilized for the synthesis of IONPs of different size range (Khalil et al., 2017; Arularasu et al., 2018). Current reports also speculate that nanoparticles which are synthesized by using plant extracts are much more stabilized than the conventionally synthesized nanoparticles (Bibi et al., 2019) and are usually of distinct shapes like spherical, cubical, cylindrical, needles, stems, prisms and dendrites (Abdullah et al., 2020). The features of synthesized nanoparticles mainly depends on the discrete criterions like type of the plant extract, volume ratio of the extract and metallic salt solutions and reaction conditions ( $\mathrm{pH}$, temperature and incubation time) (Abdullah et al., 2020; Singh et al., 2018). So, on the basis of these highlighted parameters, different methods of synthesizing iron-oxide nanoparticles have been employed by researchers which vary slightly from one another in choice of starting material, method of plant extract preparation, selection of iron salt, presence or absence of $\mathrm{NaOH}$, variable reaction condition and the method of collecting synthesized nanoparticles.

A captive work on the synthesis of Iron oxide NPs from leaves, fruits, seeds, seed coat, flowers, peels, petals or whole plant generally begins with the washing of starting material followed by extraction. As elaborated in Figure 3 the most common procedure involves, collection of plant parts either fresh, dried form from the market or from waste (in case of banana peels and pruned tea) and rinsing with tap water followed by their washing either with distilled or deionized water. Nextly, these washed plant parts are generally kept for drying at room temperature (Khalil et al., 2017; Beheshtkhoo et al., 2018; Lohrasbi et al., 2019) or in oven at $40-60^{\circ} \mathrm{C}$ for $1-4 \mathrm{~h}$, (Majumder et al., 2019; Bhuiyan et al., 2020; Izadiyan et al., 2020; Ruiz et al., 2020), under shade (Razack et al., 2020), in sunlight (Arularasu et al., 2018) or air dried (Kanagasubbulakshmi and Kadirvelu, 2017; Karade et al., 2019; Jamzad and Bidkorpeh, 2020) succeeded by weighing. After this, the sample is grounded into fine powder by using pestle mortar/blender/willy mill/electric grinder (Khalil et al., 2017; Bibi et al., 2019; Hooda and Sharma, 2020; Izadiyan et al., 2020; Razack et al., 2020; Ting and Chin, 2020). Distilled water, double distilled water, methanol or ethanol: water (1:1) is added to the powder and the content is boiled under continuous stirring by using magnetic stirrer hot plate, water bath or heater mantle under reflux (Beheshtkhoo et al., 2018; Lohrasbi et al., 2019). An optional step of filtration using a cheese cloth was performed (before boiling) by some researchers (Ting and Chin, 2020). Boiling step was replaced by shaking for $120 \mathrm{~min}$ in the protocol used by Bibi et al. (2019). But in case of Gardenia resinifera and Kappaphycus alvarezii extraction, protocol shows slight variation as powdered form of leaves was soaked in methanol solution for two days at room temperature followed by centrifugation at $1,000 \mathrm{rpm}$ for $10 \mathrm{~min}$ whereas, in case of Kappaphycus alvarezii, powder was soaked in distilled water for 1 day before use. In other studies on Borassus flabellifer and Terminalia belerica extraction was carried out using soxhlet apparatus employing ethanol or distilled water (Akhter et al., 2019) as a solvent. The extraction mixture is finally filtered using Whatman Filter Paper, filter membrane $(0.45 \mu \mathrm{m})$, nylon mesh, Millipore hydrophillic filter $(0.22 \mu \mathrm{m})$ or under vacuum conditions. In some studies by Beheshtkhoo et al. (2018), Chauhan and Upadhyay (2019), Jamzad and Bidkorpeh(2020), Lohrasbi et al. (2019) and Razack et al. (2020) green synthesis of NPs by plants shows a supplementary step of centrifugation (2000 rpm for $5 \mathrm{~min}$ and 7,000 rpm for $15 \mathrm{~min}$ ) of filtrate next to filtration. In Carica papaya (Bhuiyan et al., 2020) extract preparation, the filtrate obtained was concentrated using rotary evaporator. The clear solution obtained either after filtration or centrifugation was considered as a sample for synthesis of IONPs. Some volume of the extract is then mixed with precursor salt solutions (Iron Sulfate heptahydrate, $\mathrm{FeCl}_{3} \cdot 6 \mathrm{H}_{2} \mathrm{O} \quad\left(\mathrm{Fe} \mathrm{NO}_{3}\right)_{3} .9 \mathrm{H}_{2} \mathrm{O}, \mathrm{FeSO}_{4}, \mathrm{FeCl}_{3}, \quad \mathrm{FeCl}_{2} .4 \mathrm{H}_{2} \mathrm{O}$, $\mathrm{FeCl}_{2}, \mathrm{FeSO}_{4} .5 \mathrm{H}_{2} \mathrm{O}$ ) of different molarity as mentioned in Table 1. and finally mixture is heated $\left(60-85^{\circ} \mathrm{C}\right.$ range) or vigorously stirred for preferred time (30-60 min) and temperatures as in the protocol. Incubation of plant extract with the precursor salts changes the color of solution depending upon the type of iron salts used that visually intensifies with the production of nanoparticles. After the synthesis, some methods further proceed by continuous stirring over magnetic stirrer (Kanagasubbulakshmi and Kadirvelu, 2017; Arularasu et al., 2018; Beheshtkhoo et al., 2018; Akhter et al., 2019; Devi et al., 2019; Karpagavinayagam andVedhi, 2019; Lohrasbi et al., 2019; Majumder et al., 2019; Asghar et al., 2020; Bhuiyan et al., 2020; Hooda and Sharma, 2020; Izadiyan et al., 2020; Jamzad and Bidkorpeh, 2020; Madubuonu et al., 2020; Periakaruppan et al., 2020; Razack et al., 2020; Rong et al., 2020; Ting and Chin, 2020), centrifugation step (Kanagasubbulakshmi and Kadirvelu, 2017; Kanagasubbulakshmi and Kadirvelu, 2017; Khalil et al., 2017; Arularasu et al., 2018; Beheshtkhoo et al., 2018; Bibi et al., 2019; Chauhan and Upadhyay, 2019; Devi et al., 2019; Karpagavinayagam andVedhi, 2019; Lohrasbi et al., 2019; Vasantharaj et al., 2019; Asghar et al., 2020; Bhuiyan et al., 2020; Hooda and Sharma, 2020; Izadiyan et al., 2020; Jamzad and Bidkorpeh, 2020; Periakaruppan et al., 2020; Razack et al., 2020; Rong et al., 2020; Ting and Chin, 2020) or magnetic decantation (Madubuonu et al., 2020; Ruiz et al., 2020) at preferred time, temperature and rpm. In Karade et al. (2019) method after mixing of extract with the precursor salt, $2 \mathrm{M}$ sodium acetate salt was added at room temperature followed by heating at $80^{\circ} \mathrm{C}$ for $2 \mathrm{~h}$. All the stirring and centrifugation steps are excluded in this protocol. The pellets of IONPs obtained are subjected for final washing with distilled water, ethanol, deionized water, methanol or double distilled water. The synthesis finally concludes with drying of the pellet (NPs) either in hot air oven, vacuum drying (Kanagasubbulakshmi and Kadirvelu, 2017), air dried (Karade et al., 2019), furnace (Bibi et al., 2019), vacuum hot air oven (Karpagavinayagam andVedhi, 2019) or in the room 
TABLE 1 | Biosynthesis of Iron oxide nanoparticles by using plants.

\begin{tabular}{|c|c|c|c|c|c|c|c|c|c|}
\hline Sr.No & $\begin{array}{l}\text { Name } \\
\text { of the } \\
\text { plant }\end{array}$ & $\begin{array}{l}\text { Bio-material } \\
\text { used }\end{array}$ & Quantity & $\begin{array}{l}\text { Iron } \\
\text { precursor } \\
\text { used }\end{array}$ & $\begin{array}{l}\text { Size } \\
(\mathrm{nm})\end{array}$ & Shape & Magnetization & Applications & References \\
\hline 1 & Sageretia thea & $\begin{array}{l}\text { Fine powdered } \\
\text { fresh leaves }\end{array}$ & $\begin{array}{l}30 \mathrm{~g} \text { in } 200 \mathrm{ml} \\
\text { distilled water }\end{array}$ & Iron sulfate heptahydrate & $-29 \mathrm{~nm}$ & $\begin{array}{l}\text { Tetragonal } \\
\text { crystalline }\end{array}$ & - & $\begin{array}{l}\text { Anticancer, antimicrobial, } \\
\text { antileishmanias, } \\
\text { cytotoxicity assay }\end{array}$ & Khalil et al. (2017) \\
\hline 2 & $\begin{array}{l}\text { Lagenaria } \\
\text { siceraria }\end{array}$ & Air dried leaves & $\begin{array}{l}5 \mathrm{~g} \text { in } 100 \mathrm{ml} \\
\text { double distilled } \\
\text { water (boiling) }\end{array}$ & $\mathrm{FeCl}_{3} .6 \mathrm{H}_{2} \mathrm{O}(0.01 \mathrm{M})$ & $30-100 \mathrm{~nm}$ & Cube & - & Antimicrobial & $\begin{array}{l}\text { Kanagasubbulakshmi and } \\
\text { Kadirvelu (2017) }\end{array}$ \\
\hline 3 & $\begin{array}{l}\text { Daphne } \\
\text { mezereum }\end{array}$ & Dried leaves & $\begin{array}{l}5 \%(\mathrm{w} / \mathrm{v}) \text { i.e., } 5 \mathrm{~g} \\
\text { in } 100 \mathrm{ml} \\
\text { deionized water }\end{array}$ & $\mathrm{FeCl}_{3} \cdot 6 \mathrm{H}_{2} \mathrm{O}(0.1 \mathrm{M})$ & $6.5-14.9 \mathrm{~nm}$ & Spherical & Paramagnetic & Dye removal & Beheshtkhoo et al. (2018) \\
\hline 4 & Ruellia tuberose & Leaf extract & $\begin{array}{l}5 \mathrm{~g} \text { in } 100 \mathrm{ml} \\
\text { distilled water }\end{array}$ & $\mathrm{FeSO}_{4}(1 \mathrm{M}), 1 \mathrm{~g} \mathrm{NaOH}$ & $20-80$ nm & Hexagonal rods & - & $\begin{array}{l}\text { Photocatalytic, } \\
\text { antibacterial }\end{array}$ & Vasantharaj et al. (2019) \\
\hline 5 & $\begin{array}{l}\text { Kappaphycus } \\
\text { alvarezii }\end{array}$ & $\begin{array}{l}\text { Dried whole } \\
\text { plant }\end{array}$ & $\begin{array}{l}1 \mathrm{~g} \text { in } 25 \mathrm{ml} \text { of } \\
\text { distilled water }\end{array}$ & $\begin{array}{l}\mathrm{FeCl}_{2} \cdot 4 \mathrm{H}_{2} \mathrm{O} \\
\text {,FeCl } 3.6 \mathrm{H}_{2} \mathrm{O} \text {, glycine } \\
\text { (amino acid) }\left(\mathrm{C}_{2} \mathrm{H}_{5} \mathrm{NH}_{2}\right)\end{array}$ & $10-30 \mathrm{~nm}$ & $\begin{array}{l}\text { Irregular or } \\
\text { hexagonal }\end{array}$ & $\begin{array}{l}\text { Ferromagnetic }\left(\mathrm{M}_{\mathrm{s}} 18.89\right. \\
\left.\text { emu/g,M } \mathrm{M}_{\mathrm{r}} 1.54 \mathrm{emu} / \mathrm{g}\right)\end{array}$ & $\begin{array}{l}\text { Photocatalytic, } \\
\text { antibacterial }\end{array}$ & Arularasu et al. (2018) \\
\hline 6 & $\begin{array}{l}\text { Platanus } \\
\text { orientalis }\end{array}$ & Dried leaves & $\begin{array}{l}5 \mathrm{~g} \text { grinded dry } \\
\text { leaves in } \\
50 \mathrm{ml} \text { DDW }\end{array}$ & $\mathrm{Fe}\left(\mathrm{NO}_{3}\right)_{3} .9 \mathrm{H}_{2} \mathrm{O}(99.8 \%)$ & $38 \mathrm{~nm}$ & Spherical & - & Antifungal & Devi et al. (2019) \\
\hline 7 & $\begin{array}{l}\text { Avecinnia } \\
\text { marina }\end{array}$ & Flowers & $\begin{array}{l}5 \mathrm{~g} \text { in } 100 \mathrm{ml} \\
\text { millipore distilled } \\
\text { water }\end{array}$ & $\begin{array}{l}\text { Aqueous ferric chloride } \\
(1 \mathrm{~m} \mathrm{~mol})\end{array}$ & $10-40 \mathrm{~nm}$ & $\begin{array}{l}\text { Honeycomb like, } \\
\text { smooth surface, non } \\
\text { uniform }\end{array}$ & - & Methanol oxidation & $\begin{array}{l}\text { Karpagavinayagam and } \\
\text { Vedhi (2019) }\end{array}$ \\
\hline 8 & $\begin{array}{l}\text { Punica } \\
\text { granatum }\end{array}$ & Seeds & $\begin{array}{l}20 \mathrm{~g} \text { in } 250 \mathrm{ml} \text { of } \\
\text { distilled water }\end{array}$ & Iron chloride (1 M) & $25-55 \mathrm{~nm}$ & $\begin{array}{l}\text { Variable, semi- } \\
\text { spherical } \\
\text { (aggregated) }\end{array}$ & - & Photocatalytic & Bibi et al. (2019) \\
\hline 9 & Plantago major & $\begin{array}{l}\text { Aqueous leaf } \\
\text { extract }\end{array}$ & $\begin{array}{l}5 \mathrm{~g} \text { dried leaves in } \\
100 \mathrm{ml} \text { deionized } \\
\text { water }\end{array}$ & $\mathrm{FeCl}_{3} .6 \mathrm{H}_{2} \mathrm{O}(0.1 \mathrm{M})$ & 4.6-30.6 nm & Spherical & Paramagnetic & Dye removal & Lohrasbi et al. (2019) \\
\hline 10 & $\begin{array}{l}\text { Lawsonia } \\
\text { inermis }\end{array}$ & Powdered plant & $\begin{array}{l}5 \mathrm{~g} \text { powder in } \\
50 \mathrm{ml} \text { deionized } \\
\text { water }\end{array}$ & $\begin{array}{l}\mathrm{FeSO} 4.7 \mathrm{H} 20(0.02 \mathrm{M}) \\
\mathrm{NaOH}(1 \mathrm{~mol} / \mathrm{L})\end{array}$ & $150-200 \mathrm{~nm}$ & Spherical & - & Antimicrobial & $\begin{array}{l}\text { Chauhan and Upadhyay } \\
\text { (2019) }\end{array}$ \\
\hline 11 & $\begin{array}{l}\text { Terminalia } \\
\text { belerica }\end{array}$ & Fruits & $\begin{array}{l}10.5 \mathrm{~g} \text { herb } \\
\text { powder in } 300 \mathrm{ml} \\
\text { water }\end{array}$ & Ferrous chloride (0.1 M) & $15-23 \mathrm{~nm}$ & Spherical & - & Antibacterial & Akhter et al. (2019) \\
\hline 12 & $\begin{array}{l}\text { Musa } \\
\text { paradisiaca }\end{array}$ & $\begin{array}{l}\text { Powdered } \\
\text { waste banana } \\
\text { peels (dried) }\end{array}$ & - & $\mathrm{FeCl}_{3}(0.1 \mathrm{M})$ & $60 \mathrm{~nm}$ & Cylindrical & - & Arsenic remediation & Majumder et al. (2019) \\
\hline 13 & $\begin{array}{l}\text { Gardenia } \\
\text { resinifera }\end{array}$ & $\begin{array}{l}\text { Powdered fresh } \\
\text { leaves }\end{array}$ & $\begin{array}{l}10 \mathrm{~g} \text { powder in } \\
\text { methanol }\end{array}$ & $\begin{array}{l}\mathrm{FeCl}_{3} .6 \mathrm{H}_{2} \mathrm{O}(0.4 \mathrm{mM}) \\
\text { sodium acetate }(2 \mathrm{M})\end{array}$ & $3-8 \mathrm{~nm}$ & Spherical & Superparamagnetic & Cytotoxic assay & Karade et al. (2019) \\
\hline 14 & $\begin{array}{l}\text { Borassus } \\
\text { flabellifer }\end{array}$ & Seed coat & $\begin{array}{l}30 \mathrm{~g} \text { crushed } \\
\text { seeds in } 250 \mathrm{ml} \\
\text { ethanol }\end{array}$ & $\begin{array}{l}\text { Ferric chloride }(0.2 \mathrm{M}) \\
\text { and ferrous sulfate } \\
(0.1 \mathrm{M})(2: 1) \\
\mathrm{NaOH}(0.1 \mathrm{M})\end{array}$ & 30-200 nm & Hexagonal & - & $\begin{array}{l}\text { Antimicrobial, } \\
\text { antioxidant, cytotoxic } \\
\text { assay }\end{array}$ & \\
\hline 15 & $\begin{array}{l}\text { Hibiscus rosa- } \\
\text { sinensis }\end{array}$ & Dried petals & $\begin{array}{l}2 \mathrm{~g} \text { petals } \\
\text { powder in } 100 \mathrm{ml} \\
\text { distilled water }\end{array}$ & $\begin{array}{l}\text { Ferric choride ( } 25 \mathrm{mM}) \\
\text { and ferrous chloride } \\
(25 \mathrm{mM})(2: 1)\end{array}$ & $65 \mathrm{~nm}$ & Spinel & - & Biscuits fortification & Razack et al. (2020) \\
\hline 16 & Carica papaya & Dried leaves & $\begin{array}{l}20 \mathrm{~g} \text { fine powder } \\
\text { in } 1 \mathrm{~L} \text { deionized } \\
\text { water (boiling) }\end{array}$ & $\begin{array}{l}\mathrm{FeCl}_{3} \cdot 6 \mathrm{H}_{2} \mathrm{O}(0.1 \mathrm{M}) \\
\mathrm{NaOH}(1 \mathrm{M})\end{array}$ & $2.159 \mathrm{~nm}$ & $\begin{array}{l}\text { Not uniform } \\
\text { (agglomerated } \\
\text { particles) }\end{array}$ & - & Antibacterial & Bhuiyan et al. (2020) \\
\hline
\end{tabular}


TABLE 1 | (Continued) Biosynthesis of Iron oxide nanoparticles by using plants.

\begin{tabular}{|c|c|c|c|c|c|c|c|c|c|}
\hline Sr.No & $\begin{array}{l}\text { Name } \\
\text { of the } \\
\text { plant }\end{array}$ & $\begin{array}{l}\text { Bio-material } \\
\text { used }\end{array}$ & Quantity & $\begin{array}{l}\text { Iron } \\
\text { precursor } \\
\text { used }\end{array}$ & $\begin{array}{l}\text { Size } \\
(\mathrm{nm})\end{array}$ & Shape & Magnetization & Applications & References \\
\hline 17 & $\begin{array}{l}\text { Psidium } \\
\text { guajava }\end{array}$ & $\begin{array}{l}\text { Fresh dried } \\
\text { leaves }\end{array}$ & $\begin{array}{l}10 \mathrm{~g} \text { crushed } \\
\text { leaves in } 100 \mathrm{ml} \\
\text { distilled water }\end{array}$ & $\mathrm{FeCl}_{3} \cdot 6 \mathrm{H}_{2} \mathrm{O}$ & $1-5 \mathrm{~nm}$ & Spherical & Superparamagnetic & Antibacterial & Madubuonu et al. (2020) \\
\hline 18 & Citrus & Fresh leaves & $\begin{array}{l}25 \mathrm{~g} \text { leaves in } \\
250 \mathrm{ml} \mathrm{DW}\end{array}$ & Iron chloride (0.1 mM) & $15-80 \mathrm{~nm}$ & Spherical & - & Antibacterial & $\begin{array}{l}\text { Hooda and Sharma } \\
(2020)\end{array}$ \\
\hline 19 & $\begin{array}{l}\text { Malus pumila } \\
\text { (apple) }\end{array}$ & Peels & $\begin{array}{l}75 \mathrm{~g} \text { peels in } \\
300 \mathrm{ml} \text { mili- } \\
\mathrm{Q} \mathrm{H}_{2} \mathrm{O}\end{array}$ & $\begin{array}{l}\mathrm{FeCl}_{2} \cdot 4 \mathrm{H}_{2} \mathrm{O}(20 \mathrm{mM}) \\
\mathrm{FeCl}_{3} \cdot 6 \mathrm{H}_{2} \mathrm{O}(40 \mathrm{mM}) \\
\mathrm{NaOH}(1 \mathrm{M})\end{array}$ & $50-100 \mathrm{~nm}$ & $\begin{array}{l}\text { Elliptical and } \\
\text { spherical }\end{array}$ & - & Decolorization of dye & Ting and Chin (2020) \\
\hline 20 & $\begin{array}{l}\text { Camellia } \\
\text { sinensis } L\end{array}$ & $\begin{array}{l}\text { Grinded waste } \\
\text { of pruned teas }\end{array}$ & $\begin{array}{l}10 \mathrm{~g} \text { of pruned } \\
\text { tea in } 100 \mathrm{ml} \\
\text { deionized water }\end{array}$ & $\begin{array}{l}\mathrm{FeSO}_{4} .5 \mathrm{H}_{2} \mathrm{O}(0.1 \mathrm{M}) \\
\mathrm{NaOH}(0.5 \mathrm{M})\end{array}$ & $28.5 \mathrm{~nm}$ & Regular spherical & Superparamagnetic & Antioxidant & $\begin{array}{l}\text { Periakaruppan et al. } \\
\text { (2020) }\end{array}$ \\
\hline 21 & $\begin{array}{l}\text { Syzygium } \\
\text { cumini }\end{array}$ & Leaves & $\begin{array}{l}10 \mathrm{~g} \text { chopped } \\
\text { leaves in } 100 \mathrm{ml} \\
\text { deionized water }\end{array}$ & $\mathrm{FeCl}_{3}(0.010 \mathrm{mo} / \mathrm{L})$ & $40-52 \mathrm{~nm}$ & Spherical & - & $\begin{array}{l}\text { Antibacterial, antifungal, } \\
\text { aflatoxin } B_{1} \text { adsorption }\end{array}$ & Asghar et al. (2020) \\
\hline 22 & Juglans regia & $\begin{array}{l}\text { Dried green } \\
\text { husk }\end{array}$ & $\begin{array}{l}1 \mathrm{~g} \text { green husk in } \\
100 \mathrm{ml} \text { boiling } \\
\text { water }\end{array}$ & $\begin{array}{l}\mathrm{FeCl}_{3} \cdot 6 \mathrm{H}_{2} \mathrm{O}(97 \%) \\
\mathrm{FeCl}_{2} \cdot 4 \mathrm{H}_{2} \mathrm{O}(99 \%) \\
\mathrm{NaOH}(2 \mathrm{M})\end{array}$ & $12.6 \mathrm{~nm}$ & Cubic & - & Cytotoxic assay & Izadiyan et al. (2020) \\
\hline 23 & $\begin{array}{l}\text { Pyrus } \\
\text { sinkiangensis } \\
\text { Yu }\end{array}$ & Peels & $\begin{array}{l}27 \mathrm{~g} \text { peels in } \\
360 \mathrm{ml} \text { ethanol } \\
\text { and water mixture } \\
(1: 1)\end{array}$ & $\mathrm{FeSO}_{4} .7 \mathrm{H}_{2} \mathrm{O}(0.1 \mathrm{M})$ & $10-90 \mathrm{~nm}$ & Irregulary shaped & - & Cr (IV) removal & Rong et al. (2020) \\
\hline 24 & $\begin{array}{l}\text { Cymbopogon } \\
\text { citratus }\end{array}$ & $\begin{array}{l}\text { Powdered } \\
\text { leaves }\end{array}$ & $\begin{array}{l}100 \mathrm{~g} \text { powder in } \\
800 \mathrm{ml} \mathrm{DW}\end{array}$ & $\begin{array}{l}\mathrm{FeCl} l_{3} .6 \mathrm{H}_{2} \mathrm{O}(0.26 \mathrm{M} \text { and } \\
0.52), \mathrm{Na}_{2} \mathrm{CO}_{3}\end{array}$ & $9 \pm 4 \mathrm{~nm}$ & Irregular cubic & $\begin{array}{l}\text { Superparamagnetic }\left(M_{S}\right. \\
=28 \mathrm{emu} / \mathrm{g})\end{array}$ & Nanotoxicological & Ruiz et al. (2020) \\
\hline 25 & Laurus nobilis L & Leaves & $\begin{array}{l}20 \mathrm{~g} \text { leaves in } \\
200 \mathrm{ml} \mathrm{DW}\end{array}$ & $\mathrm{FeCl}_{3} .6 \mathrm{H}_{2} \mathrm{O}(0.1 \mathrm{M})$ & $\begin{array}{l}8.03 \pm \\
8.99 \mathrm{~nm}\end{array}$ & Spherical & - & Antimicrobial & $\begin{array}{l}\text { Jamzad and Bidkorpeh } \\
\text { (2020) }\end{array}$ \\
\hline
\end{tabular}


(Devi et al., 2019) at desired temperature conditions and time. Extra step of annealing at $500^{\circ} \mathrm{C}$ for $2 \mathrm{~h}$ was done after drying of NPs (Khalil et al., 2017; Arularasu et al., 2018) but in Razack et al. (2020) biosynthesis method dried iron oxide nanoparticles are further treated for calcination in muffle furnace at $400^{\circ} \mathrm{C}$ for $3 \mathrm{~h}$. In the protocol followed by Chauhan and Upadhyay (2019) for the synthesis of IONPs from Lawsonia inermis (whole plant extract), nanoparticles obtained were capped with tyrosine by dispersing the NPs, in the tyrosine solution for $2 \mathrm{~h}$ at $4^{\circ} \mathrm{C}$ with continuous stirring followed by washing with deionized water and methanol before the final drying of the NPs. The synthesized nanoparticles are functionally characterized by using different techniques. Preliminary characterization is done by using UVVIS spectrophotometry. Further analysis of NPs is performed by Fourier Transform Infrared Spectroscopy (FTIR) (surface functional groups detection), $\mathrm{X}$ ray diffractometer (for crystal size determination based on Debye-Scherrer's equation), Energy-dispersive $\mathrm{X}$ ray spectrometer (EDS) (for determining elemental composition), High-resolution Scanning Electron Microscopy (SEM) and Transmission Electron Microscopy (HRTEM) (for size and shape determination), Thermal-gravimetric differential thermal analysis (for estimating the incorporation of bioactive components of the plants extract by studying the \% weight loss of the nanoparticles by giving heat treatment $\left(30-800^{\circ} \mathrm{C}\right)$, Zeta Potential analysis (helps in elucidating surface properties) and most important characteristics i.e., magnetization (Ferromagnetic, Paramagnetic and Superparamagnetic) is studied by using Vibrating Sample Magnetometer (VSM) by providing magnetic field. The brief information gathered from various recent reports is summarized in the tabular form (Table 1) below.

\section{BIOSYNTHESIS OF IRON OXIDE NANOPARTICLES USING FUNGI}

Extracellular synthesis of iron oxide nanoparticles by using fungal species is considered to be advantageous bearing in mind the ease of scale up, use of economical raw materials for growth, high biomass forming capacity, simple downstreaming steps, low toxicity of residue and economic feasibility (Tarafdar and Ralia, 2013; Guilger-Casagrande and Lima, 2019; Chatterjee et al., 2020). In addition to this, fungal species exhibit superior tolerance and bioaccumulation property which aid the synthesis of metal nanoparticles (Agarwal et al., 2017). The interactions between microorganisms and metals have been well studied (Beveridge et al., 1996) and this capability of microbes has been employed to accumulate and/or extract metals in various biological processes such as bioleaching, heavy metal removal and bioremediation (Gericke and Pinches, 2006). Fungi are known to secrete large amount of extracellular enzymes which are competent of hydrolyzing metals. This enzymatic reduction of metal ions is predicted to be responsible for the synthesis of various extracellularly synthesized nanoparticles. One such enzyme found in fungi is nitrate reductase (Abdeen et al., 2016). Although, the overall mechanisms of Metal nanoparticles (MNPs) synthesis using fungi are not completely understood. The MNPs synthesis by fungi is considered to be relied on the biological material used and the applied reaction conditions. Biological material includes the strain of microorganism used, the growth parameters and method of sample preparation whereas the reaction conditions stress on metal precursor used, concentration of metal precursor, $\mathrm{pH}$, temperature of reaction (Silva et al., 2015). While reviewing the literature one would come across a great degree of variability with regard to the starting bio-material used for biosynthesis. Some methods used fungal biomass to synthesize the nanoparticles, others used the cell free filtrate of the fungal culture or fungal biomass homogenate whereas some have employed fungal cell filtrate (Figure 3). The most widely employed method involved growing the fungi in appropriate growth medium followed by the separation of fungal mycelia by centrifugation. The mycelia thus obtained is mixed with a metal precursor salt and incubated at $28^{\circ} \mathrm{C}$ for $4-5$ days. The further filtration of this solution gives a suspension containing synthesized nanoparticles (Kaul et al., 2012; Bhargava et al., 2013). In another method the fungi are cultured in a suitable media and the mycelia is separated by filtration. After thorough washing with sterile distilled water the fungal biomass is dispensed in sterile distilled water and incubated on rotary shaker for 1-5 days. Upon incubation, cell free filtrate (CFF) is collected by filtering out mycelium with the aid of Whatman filter paper 1. and obtained cell free filtrate is treated with iron precursor salt mixture comprising ferric chloride $\left(\mathrm{FeCl}_{3} \cdot 6 \mathrm{H}_{2} \mathrm{O}\right)$ and ferrous sulfate $\left(\mathrm{FeSO}_{4} \cdot 7 \mathrm{H}_{2} \mathrm{O}\right)$ in 2:1 $\mathrm{M}$ ratio (Chatterjee et al., 2020), $\mathrm{FeCl}_{3}\left(10^{-3} \mathrm{M}\right.$ ) (Tarafdar and Ralia, 2013) and incubated again on the rotary shaker for few $h$ to achieve the synthesis of IONPs. Another method used by Abdeen et al. (2016) represents a blend of microbial and physical process for the synthesis of iron oxide nanoparticles. In this method a fine homogenate of fungal mycelium was prepared in distilled water using a cyclomixer. To this homogenate metal precursor salt $\mathrm{FeCl}_{3}$ or $\mathrm{FeSO}_{4}$ at the concentration of $2000 \mathrm{ppm}$ was added. The resulting mixture is incubated for 6 days under static condition. The synthesized IONP's were collected by centrifugation and were washed thoroughly with ethanol. The further drying of the nanoparticles was achieved with the help of a supercritical pressure reactor at temperature of $300^{\circ} \mathrm{C}$ and 850 psi pressure. In one more dramatic variation, fungal cell filtrate (FCF) was used for the synthesis of iron oxide nanoparticles. In this method the selected fungal strain was cultured in the appropriate medium and on the completion of incubation period the culture medium is filtered through Whatman filter paper 1. using a vacuum pump. The filtrate thus obtained is centrifuged and re-filtered to obtain the final fungal cell filtrate (FCF). Equal volume of FCF and solution containing ferric trichloride $\left(\mathrm{FeCl}_{3}\right)$ and ferric dichloride $\left(\mathrm{FeCl}_{2}\right)$ salt solution $(2: 1 \mathrm{mM}$ final concentration) are agitated at room temperature for just $5 \mathrm{~min}$. An immediate visual change in color demonstrates the synthesis of IONP's (Mahanty et al., 2019). This seems to be the simplest method for the synthesis of IONPs by fungus, surpassing the need of tedious filtration procedures and expensive equipments. In one such study, Iron oxide nanoparticles were synthesized from the cell free extract of 
TABLE 2 | Biosynthesis of Iron oxide nanoparticles by using fungi.

\begin{tabular}{|c|c|c|c|c|c|c|c|c|}
\hline Sr.No & $\begin{array}{l}\text { Fungal } \\
\text { strain }\end{array}$ & $\begin{array}{l}\text { Bio- } \\
\text { material } \\
\text { used }\end{array}$ & $\begin{array}{l}\text { Iron } \\
\text { precursor } \\
\text { used }\end{array}$ & $\begin{array}{l}\text { Size } \\
\text { (nm) }\end{array}$ & Shape & Magnetization & Applications & References \\
\hline 1 & $\begin{array}{l}\text { Fusarium } \\
\text { oxysporum }\end{array}$ & $\begin{array}{l}\text { Fungal } \\
\text { biomass }\end{array}$ & $\begin{array}{l}\mathrm{K}_{3}\left[\mathrm{Fe}(\mathrm{CN})_{6}\right] \text { and } \mathrm{K}_{4} \\
{\left[\mathrm{Fe}(\mathrm{CN})_{6}\right](2: 1 \mathrm{mM})}\end{array}$ & $20-50 \mathrm{~nm}$ & $\begin{array}{l}\text { Quasi- } \\
\text { spherical }\end{array}$ & Ferrimagnetic & - & $\begin{array}{l}\text { Bharde et al. } \\
\text { (2006) }\end{array}$ \\
\hline 2 & Verticillium sp & $\begin{array}{l}\text { Fungal } \\
\text { biomass }\end{array}$ & $\begin{array}{l}\mathrm{K}_{3}\left[\mathrm{Fe}(\mathrm{CN})_{6}\right] \text { and } \mathrm{K}_{4} \\
{\left[\mathrm{Fe}(\mathrm{CN})_{6}\right](2: 1 \mathrm{mM})}\end{array}$ & $100-400 \mathrm{~nm}$ & $\begin{array}{l}\text { Cubo- } \\
\text { octahedrally }\end{array}$ & Ferrimagnetic & - & $\begin{array}{l}\text { Bharde et al. } \\
\text { (2006) }\end{array}$ \\
\hline 3 & Curvularia lunata & $\begin{array}{l}\text { Fungal } \\
\text { biomass }\end{array}$ & $\mathrm{Fe}_{2} \mathrm{O}_{3}(1,000 \mathrm{ppm})$ & $20.7 \mathrm{~nm}$ & - & - & - & $\begin{array}{l}\text { Kaul et al. } \\
(2012)\end{array}$ \\
\hline 4 & $\begin{array}{l}\text { Chaetomium } \\
\text { globosum }\end{array}$ & $\begin{array}{l}\text { Fungal } \\
\text { biomass }\end{array}$ & $\mathrm{Fe}_{2} \mathrm{O}_{3}(1,000 \mathrm{ppm})$ & $25 \mathrm{~nm}$ & - & - & - & $\begin{array}{l}\text { Kaul et al. } \\
\text { (2012) }\end{array}$ \\
\hline 5 & A. fumigatus & $\begin{array}{l}\text { Fungal } \\
\text { biomass }\end{array}$ & $\mathrm{Fe}_{2} \mathrm{O}_{3}(1,000 \mathrm{ppm})$ & $42.4 \mathrm{~nm}$ & - & - & - & $\begin{array}{l}\text { Kaul et al. } \\
\text { (2012) }\end{array}$ \\
\hline 6 & A. wentii & $\begin{array}{l}\text { Fungal } \\
\text { biomass }\end{array}$ & $\mathrm{Fe}_{2} \mathrm{O}_{3}(1,000 \mathrm{ppm})$ & $46 \mathrm{~nm}$ & - & - & - & $\begin{array}{l}\text { Kaul et al. } \\
\text { (2012) }\end{array}$ \\
\hline 7 & $\begin{array}{l}\text { Aspergillus oryzae } \\
\text { TFR9 }\end{array}$ & $\begin{array}{l}\text { Cell free } \\
\text { filtrate }\end{array}$ & $\mathrm{FeCl}_{3}(1 \mathrm{mM})$ & $10-24.6 \mathrm{~nm}$ & Spherical & - & - & $\begin{array}{l}\text { Tarafdar and } \\
\text { Ralia (2013) }\end{array}$ \\
\hline 8 & $\begin{array}{l}\text { Aspergillus } \\
\text { japonicus }\end{array}$ & $\begin{array}{l}\text { Fungal } \\
\text { biomass }\end{array}$ & $\begin{array}{l}\text { Potassium ferricyanide } \\
\mathrm{K}_{3}\left[\mathrm{Fe}(\mathrm{CN})_{6}\right] \text { and } \\
\text { potassium ferrocyanide } \\
\mathrm{K}_{4}\left[\mathrm{Fe}(\mathrm{CN})_{6}\right](1 \mathrm{mM} \text { : } \\
0.5 \mathrm{mM})\end{array}$ & $60-70 \mathrm{~nm}$ & Cubic & - & - & $\begin{array}{l}\text { Bhargava } \\
\text { et al. (2013) }\end{array}$ \\
\hline 9 & Aspergillus sp & $\begin{array}{l}\text { Fungal } \\
\text { biomass }\end{array}$ & $\mathrm{FeSO}_{4}(3.0 \mathrm{mM})$ & $5-200 \mathrm{~nm}$ & Spherical & - & - & $\begin{array}{l}\text { Pavani and } \\
\text { Kumar (2013) }\end{array}$ \\
\hline 10 & $\begin{array}{l}\text { Alterneria } \\
\text { alternata }\end{array}$ & $\begin{array}{l}\text { Fungal } \\
\text { biomass }\end{array}$ & Iron (III) nitrate (1 mM) & $9 \mathrm{~nm}$ & Spherical & - & Antibacterial & $\begin{array}{l}\text { Mohamed } \\
\text { et al. (2015) }\end{array}$ \\
\hline 11 & $\begin{array}{l}\text { Aspergillus niger } \\
\text { YESM }\end{array}$ & $\begin{array}{l}\text { Fungal } \\
\text { homogenate }\end{array}$ & $\begin{array}{l}\mathrm{FeCl}_{3}, \mathrm{FeSO}_{4} \\
\text { (2000ppm each) }\end{array}$ & $\begin{array}{l}18 \mathrm{~nm} \text { for } \mathrm{Fe} \\
\text { and } 50 \mathrm{~nm} \text { for } \\
\mathrm{Fe}_{3} \mathrm{O}_{4}\end{array}$ & Spherical & $\begin{array}{l}\text { Superparamagnetic for } \mathrm{Fe} \\
\text { and ferromagnetic-like for } \\
\mathrm{Fe}_{3} \mathrm{O}_{4}\end{array}$ & - & $\begin{array}{l}\text { Abdeen et al. } \\
\text { (2016) }\end{array}$ \\
\hline 12 & $\begin{array}{l}\text { Trichoderma } \\
\text { asperellum }\end{array}$ & $\begin{array}{l}\text { Fungal cell } \\
\text { filtrate }\end{array}$ & $\mathrm{FeCl}_{2}: \mathrm{FeCl}_{3}(1: 2 \mathrm{mM})$ & $18-32 \mathrm{~nm}$ & Spherical & - & - & $\begin{array}{l}\text { Mahanty et al. } \\
\text { (2019) }\end{array}$ \\
\hline 13 & $\begin{array}{l}\text { Phialemoniopsis } \\
\text { ocularis }\end{array}$ & $\begin{array}{l}\text { Fungal cell } \\
\text { filtrate }\end{array}$ & $\mathrm{FeCl}_{2}: \mathrm{FeCl}_{3}(1: 2 \mathrm{mM})$ & $6-22 \mathrm{~nm}$ & Spherical & - & - & $\begin{array}{l}\text { Mahanty et al. } \\
\text { (2019) }\end{array}$ \\
\hline 14 & $\begin{array}{l}\text { Fusarium } \\
\text { incarnatum }\end{array}$ & $\begin{array}{l}\text { Fungal cell } \\
\text { filtrate }\end{array}$ & $\mathrm{FeCl}_{2}: \mathrm{FeCl}_{3}(1: 2 \mathrm{mM})$ & $15-55 \mathrm{~nm}$ & Spherical & - & - & $\begin{array}{l}\text { Mahanty et al. } \\
\text { (2019) }\end{array}$ \\
\hline 15 & $\begin{array}{l}\text { Aspergillus niger } \\
\text { BSC-1 }\end{array}$ & $\begin{array}{l}\text { Cell free } \\
\text { filtrate }\end{array}$ & $\begin{array}{l}\left.\mathrm{FeCl}_{3} \cdot 6 \mathrm{H}_{2} \mathrm{O}\right) \text { and } \\
\text { ferrous sulfate }\left(\mathrm{FeSO}_{4} \text {. }\right. \\
\left.7 \mathrm{H}_{2} \mathrm{O}\right) \text { in } 2 \mathrm{mM}: 1 \mathrm{Mm}\end{array}$ & 20-40 nm & Orthorhombic & Superparamagnetic & $\begin{array}{l}\mathrm{Cr}(\mathrm{Vl}) \\
\text { removal }\end{array}$ & $\begin{array}{l}\text { Chatterjee } \\
\text { et al. }(2020)\end{array}$ \\
\hline
\end{tabular}

A. niger BSC-1. XRD analysis indicates crystalline orthorhombic structure of magnetite nanoparticles. The width of the IONPs determined using TEM was found to be in between $20-40 \mathrm{~nm}$ and the average size of $17.29 \mathrm{~nm}$ was calculated Debye-Scherrer equation. The particles exhibited superparamagnetic behavior with $55.19 \mathrm{emu} / \mathrm{g}$ of saturation magnetization, $0.0045 \mathrm{Oe}$ of coercivity and $1.61 \mathrm{emu} / \mathrm{g}$ of retentivity (Chatterjee et al., 2020). Nanoparticles synthesized by $A$. oryzae TFR9 had a sized range between 10 and $24.6 \mathrm{~nm}$ from DLS analysis. A TEM micrograph depicts the formation of spherical IONPs (Tarafdar and Ralia, 2013). The nanoparticles synthesized by mycelia homogenate of Aspergillus niger YESM under supercritical condition of ethanol yielded pure iron and major proportion of $\mathrm{Fe}_{3} \mathrm{O}_{4}$ spherical nanoparticles. The average size determined from the SEM analysis is 18 and $50 \mathrm{~nm}$ for iron and $\mathrm{Fe}_{3} \mathrm{O}_{4}$ nanoparticles, respectively. The measurement of magnetic properties reveals superparamagnetic and ferromagnetic-like behaviors for $\mathrm{Fe}$ and $\mathrm{Fe}_{3} \mathrm{O}_{4}$ nanoparticles, respectively (Abdeen et al., 2016). Concise information about the different reports encountered for the synthesis of IONP's by fungus till date can be obtained from the following Table 2 .

\section{BIOSYNTHESIS OF IRON OXIDE NANOPARTICLES USING BACTERIA}

Prokaryotic system has also been studied extensively as a key model in the field of nanotechnology due to their ubiquitous presence, fast doubling time, potential to grow under adverse conditions, inexpensive and simple media for cultivation (Pantidos and Horsfall, 2014; Fariq et al., 2017). This system has been considered as a best way for synthesis of nanoparticles of various shapes, size distribution, structural framework, physical and chemical properties by reducing metal ions (Gahlawat and Choudhury, 2019). Microorganisms cumulates and detoxicate metals by the activity of reductase enzyme, so this property has been exploited for synthesizing metallic nanoparticles by using salts as a reaction precursors (Singh et al., 2016; Alam et al., 2020). Reduction of metal ions is a crucial step in the synthesis process. It is under the control of numerous factors like functional groups on the cell wall (required for bio mineralization), strain type, environmental conditions including $\mathrm{pH}$, temperature, growth medium, concentration of salts. All the above discussed factors directly or indirectly affect the size, shape and composition and 
yield of nanoparticles (Saratale et al., 2018; Gahlawat and Choudhury, 2019; Iravani and Varma, 2020). Among them, temperature, $\mathrm{pH}$ and incubation time for the microbial culture are the paramount factors, as this green approach of synthesis is regulated by the enzymatic system for reduction of metal ions (NADH reductase), so biosynthesis depends upon optimum conditions. High temperature and $\mathrm{pH}$ completely inactivates the enzymes and halts their action, in turn, slows down the nanoparticles formation (Sundaram et al., 2012; Garg et al., 2020; Jubran et al., 2020). Besides enzymes, proteins, peptides, cofactors and organic molecules also contributes in the synthesis process as stabilizer, capping and reducing agents (Singh et al., 2016). A sequence of reports on the biosynthesis of nanoparticles indicates the deployment of cytoplasmic extracts, supernatant, extracellular polysaccharides as a reduction activator molecules (Singh et al., 2016). Generally, two distinct mechanisms i.e., intracellular and extracellular has been explored by bacteria for NPs synthesis (Javaid et al., 2018; Gahlawatand Choudhury, 2019; Grasso et al., 2020; Tsekhmistrenko et al., 2020). Intracellular synthesis is based on the ion transportation in the microbial cells. The cell wall is the main player in this process as the enzymes present in the cell wall are involved in the metal reduction whereas extracellular process is based on the aggregation of metal ions on the surface of microbial cells via electrostatic interaction between the ions and negatively charged cell wall enzymes and soluble enzymes secreted by microbes (Narayanan and Sakthivel, 2010; Hulkoti and Taranath, 2014; Punjabi et al., 2018; Singh et al., 2018; Mughal et al., 2021). Extracellular methods has achieved major success than intracellular protocols as former synthesis excludes downstream processing, centrifugation, sonication and washing steps for the recovery of product and make the process fairly cost effective (Singh et al., 2016). Thus, high-efficiency and lucrative extracellular method has more industrial applications due to easy extraction process (Srivastava and Constanti, 2012). Bacterial system generally consists of distinct defense mechanisms like extracellular precipitation, intracellular segregation, and efflux pumps to withstand with all environmental conditions. This property helps in the production of NPs with wide applications like antimicrobial, anti biofilm, anticancer and environment cleaning (dye degradation, pollutants (Cd) removal (Fang et al., 2019; Gahlawat and Choudhury, 2019).

Many reports indicates that Actinobacter sp., Thermoanaerobacter sp., Bacillus subtilis, Thiobacillus thioparus, Aquaspirillum magnetotacticum, Magnetotactic bacterium MV-1, Magnetospirillum magnetotacticum, $M$. magnetotacticum (MS-1), M. gryphiswaldense, Geobacter metallireducens GS-15, Thermophilicbacteria TOR-39, Microbacterium hominis, Bacillus licheniformis, Lactobacillus casei and Lactobacillus fermentum are the bacterial strains that has been used for both intracellular and extracellular synthesis of iron oxide nanoparticles (Gholampoor et al., 2015; Saif et al., 2016; Singh et al., 2016). Many extracellular enzymes perform the function of electron shuttle system for reducing metal ions. Research shows that some bacteria like Geothrix fermentans, Mycobacterium paratuberculosis and Shewanella oneidensi reduces $\mathrm{Fe}^{3+}$ ions in a diffusible manner by secreting some redox compounds that act as an electron shuttle between the host and substrate (Sundaram et al., 2012). Hence, this route of synthesis is clean and economically acceptable. Current review will focus mainly on the extracellular synthesis of iron oxide nanoparticles by bacterial system.

Iron oxide nanoparticles synthesis generally begins with the selection of bacteria (from soil, lyophilized culture). Isolation step includes growing the sample on the media like $\mathrm{BH} 1$ agar (Sundaram et al., 2012), Blood agar (Jubran et al., 2020) or nutrient agar (Fatemi et al., 2018) followed by their incubation under controlled conditions at $35-37^{\circ} \mathrm{C}$ for $24-48 \mathrm{~h}$ and in case of blood agar medium incubation is carried out under controlled conditions of carbon dioxide. After the achievement of sufficient growth single colony is transferred to the nutrient medium, such as Luria broth, Nutrient broth or MRS broth (Sundaram et al., 2012; Fani et al., 2018; Fatemi et al., 2018; Torabian et al., 2018; Jubran et al., 2020) followed by incubation and centrifugation to pellet out the bacterial biomass. After centrifugation most critical step of IONPs synthesis initiates by taking either supernatant (Sundaram et al., 2012; Fatemi et al., 2018; Jubran et al., 2020) or cell pellet (Fani et al., 2018; Torabian et al., 2018). The protocol after using pellet (dissolved in Phosphate Buffer Saline) required additional step of centrifugation at $3000 \mathrm{~g}$ for $10 \mathrm{~min}$ and washing including short incubation in liquid nitrogen $\left(-196^{\circ} \mathrm{C}\right)$ for $5 \mathrm{~min}$, followed by subjecting the cells to a brief heat shock by steam bathing the cell pellet at $37^{\circ} \mathrm{C}$ for $15 \mathrm{~min}$. Nextly, centrifugation is done at $12000 \mathrm{~g}$ for $30 \mathrm{~min}$ and the supernatant is collected as cytoplasmic extract (Fani et al., 2018; Torabian et al., 2018). In Kaul et al. (2012), protocol, pellets are dissolved in sterile distilled water. The supernatant and suspension of pellet is mixed with the precursor salts $\left(\mathrm{Fe}_{2} \mathrm{O}_{3}, \mathrm{FeSO}_{4}, \mathrm{FeCl}_{3} \cdot 6 \mathrm{H}_{2} \mathrm{O}\right)$ in the desired volume. The optimization of the reaction conditions is done by adjusting the $\mathrm{pH}$ in the preferred range (5-9). Lastly incubation of the mixture solution is done at different temperature conditions depending upon the strain of bacteria used. After the incubation initial indication of the nanoparticles is observed from the color change i.e., brick red to dark brown (Sundaram et al., 2012), colorless to black (Fani et al., 2018; Torabian et al., 2018), golden yellow to turbid brown (Fatemi et al., 2018) and dark green to blackish brown (Jubran et al., 2020) and the synthesized IONPs are dried and characterized. The synthesis of nanoparticles by Lactobacillus casei and Lactobacillus fermentum extract is little bit modified as there is inclusion of 10 min centrifugation at $2500 \mathrm{~g}$ to separate the synthesized nanoparticles followed by drying the pellet of NPs in the oven at $40^{\circ} \mathrm{C}$ for $24 \mathrm{~h}$ (Fani et al., 2018; Torabian et al., 2018). According to the protocol followed by Fatemi et al. (2018), the synthesized IONPs were subjected to the filtration using Whatman Filter paper No.1 and $0.2 \mu \mathrm{m}$ syringe filters. The filtrate consisting NPs was then concentrated by using rotary balloon at 20-30 rpm having steam bath temperature of $60^{\circ} \mathrm{C}$ and circulator temperature of $15-10^{\circ} \mathrm{C}$. Finally, the powder of nanoparticles were dried inside the laminar air flow under sterile conditions. In general, Lactic acid bacteria (LAB) are considered as an attractive microbial source of various nanoparticles as they are non-pathogenic and produce wide array of enzymes (Yusof et al., 2019). Moreover, the LAB are 
TABLE 3 | Biosynthesis of Iron oxide nanoparticles by using bacteria.

\begin{tabular}{|c|c|c|c|c|c|c|}
\hline Sr.No & Bacteria & Salt & Size $(n m)$ & Shape & Applications & References \\
\hline 1 & Bacillus subtilis & $\mathrm{Fe}_{2} \mathrm{O}_{3}(2 \mathrm{mM})$ & $60-80$ nm & Spherical & - & Sundaram et al. (2012) \\
\hline 2 & Alcaligens faecalis & $\begin{array}{l}\text { a. } \mathrm{Fe}_{2} \mathrm{O}_{3} \\
\text { b. } \mathrm{FeSO}_{4}(1,000 \text { ppm) }\end{array}$ & $\begin{array}{l}\text { a. } 12 \mathrm{~nm} \\
\text { b. } 43.6 \mathrm{~nm}\end{array}$ & & & Kaul et al. (2012) \\
\hline 3 & Lactobacillus casei & Iron sulfate $\left(10^{-3} \mathrm{M}\right)$ & $10-15 \mathrm{~nm}$ & Spherical & - & Torabian et al. (2018) \\
\hline 4 & Lactobacillus fermentum & Iron sulfate $\left(10^{-3} \mathrm{M}\right)$ & $10-15 \mathrm{~nm}$ & Spherical & - & Fani et al. (2018) \\
\hline 5 & Bacillus cereus (HMH1) & $\mathrm{FeCl}_{3} \cdot 6 \mathrm{H}_{2} \mathrm{O}$ & $18.8-28.3 \mathrm{~nm}$ & Spherical & Cytotoxicity assay & Fatemi et al. (2018) \\
\hline 6 & Bacillus subtilis & $\mathrm{FeCl}_{3}(2 \mathrm{mM})$ & $12-32 \mathrm{~nm}$ & Spherical & - & Jubran et al. (2020) \\
\hline
\end{tabular}

facultative anaerobic bacteria and possess high negative electro kinetic potential. Due to this, the LAB got attracted toward various metal ions under both oxidizing and reducing conditions which aids the synthesis of metal and metal oxide nanoparticles (Prasad and Jha, 2009; Królet al., 2018). In addition to this, being a Gram-positive bacteria, the cell wall consists of peptidoglycan, proteins, polysaccharides, teichoic and lipoteichoic acid which can serve as a site for biosorption and bioreduction of metal ions (Chapot-Chartier and Kulakauskas, 2014).

The most crucial step is now the characterization of NPs by different techniques like X-ray diffraction (determine the particle size of the particles by using Sherrer's equation i.e., $D=k \lambda / \beta \cos$ $\theta$ ), FT-IR spectroscopy (functional group analysis) and SEM, TEM analysis for depicting the morphology of the particles. Scanning and Transmission electron microscopy highlights that nanoparticles are spherical in shape and size falls in the $10-80 \mathrm{~nm}$ range. Table 3 illustrates the characteristics of iron oxide nanoparticles synthesized by different bacterial strains.

\section{BIOSYNTHESIS OF IRON OXIDE NANOPARTICLES USING ALGAE}

Algae is defined as photosynthetic organisms without the structure of roots and leaves. Microalgae (unicellular) and macroalgae or seaweeds (multicellular) both are extensively used in the nanotechnology field for the synthesis of distinct types of metallic (gold, silver, palladium, iron and copper) nanoparticles (Subramaniyam et al., 2016; Agarwal et al., 2017). Like plants and bacteria algal bodies are also the factory of different biomolecules like proteins, fat, carbohydrates, peptides, alkaloids, terpenes, macrolides, cell wall polysaccharides, glycoproteins (comprised of various functional groups like carbonyl, hydroxyl, carboxyl, sulfonate) and enzymes that plays a pivotal role in reduction, capping, fabrication and stabilization of nanoparticles (Siddiqi and Husen, 2016; Subramaniyam et al., 2016). Hence this approach is considered as safe, simple, cost effective and pollution free for nanoparticles production.

A significant work for the synthesis of IONPs initiates by the collection of sample. Similarly in case of algae the seaweeds are firstly washed with distilled water, followed by their drying (Salem et al., 2019; Siji et al., 2018). But in Yew et al. (2016) protocol the bleaching step is performed immediately after washing and then sample is dried under sunlight for $72 \mathrm{~h}$.
Secondly, the samples are grinded, freeze dried (Mahdavi et al., 2013), weighed, mixed with desired volume of distilled water and boiled (Mahdavi et al., 2013; Salem et al., 2019; Siji et al., 2018). In Yew et al. (2016) protocol boiling step is replaced by soaking of dried biomaterial in deionized water for 1day. The extract obtained after boiling is subjected to filtration step and filtrate is labeled as bioextract for further synthesis steps. The extract is then mixed with precursor salts $\left(\mathrm{FeCl}_{3} \cdot 6 \mathrm{H}_{2} \mathrm{O}\right.$, $\mathrm{FeCl}_{2} \cdot 4 \mathrm{H}_{2} \mathrm{O}$ or $\mathrm{FeCl}_{3}$ ) of different molarity as mentioned in Table 4. The mixture is then continuously stirred (Mahdavi et al., 2013; Yew et al., 2016; Salem et al., 2019) followed by centrifugation (Mahdavi et al., 2013; Salem et al., 2019), washing and drying. Finally the NPs are characterized by using FT-IR, $\mathrm{XRD}, \mathrm{SEM}$, TEM and VSM. All these techniques helps in elucidating the functional groups, crystal structure, size, shape and the magnetic characteristics of synthesized nanoparticles. The information about the nanoparticles obtained from various algal extracts are highlighted in Table 4.

\section{MECHANISM OF SYNTHESIS OF IONPS BY PLANTS, FUNGI, BACTERIA AND ALGAE}

Biological entities like plants, bacteria, algae and fungi have been extensively used in the synthesis of metal oxide nanoparticles (Ishak et al., 2019). These biological sources contains diverse biomolecules like alkaloids, saponins, tanins, flavonoids, proteins, carbohydrates, steroids, enzymes (NADPH dependent nitrate reductases, iron reductases), amino acids, cell wall components (alginate, laminarian), exopolysaccharides (EPS) that helps in the bioreduction, stabilization and capping of the nanoparticles (Kumar et al., 2007; Ishak et al., 2019; Jacinto et al., 2020; AlKhattaf, 2021). Underlying mechanism of bioreduction of metal ions by these key biomolecules is still not confirmed but from scientific reports it has been assumed that surface chemistry (functional groups like $-\mathrm{CHO},-\mathrm{C}=\mathrm{O},-\mathrm{COOH},-\mathrm{OH},-\mathrm{C}-\mathrm{O}-\mathrm{C}$, $-\mathrm{C}=\mathrm{C}$ ) of these reducing agents plays an important role in the reduction of metal ions. Bioreduction generally comprises of four phases-activation phase, nucleation phase, growth phase and termination phase (Figure 4). The first phase, activation phase is the slow growth phase of nanoparticles as it includes the reduction of metal ions from the precursor salt solution with the help of biomolecules present in the extract. Secondly, in the nucleation phase there is growth of the crystal on the metal nuclei with the simultaneous reduction by biometabolites. Reducing agents (like flavonoid (quercetin) adsorbed on the surface of 
TABLE 4 | Biosynthesis of IronOxide nanoparticles by using algae.

\begin{tabular}{|c|c|c|c|c|c|c|c|c|}
\hline $\begin{array}{l}\mathrm{Sr} \\
\text { No }\end{array}$ & Algae & $\begin{array}{l}\text { Bio-material } \\
\text { used }\end{array}$ & $\begin{array}{c}\text { Iron } \\
\text { precursor } \\
\text { salt }\end{array}$ & $\begin{array}{l}\text { Size } \\
(\mathrm{nm})\end{array}$ & Shape & Magnetization & Applications & References \\
\hline 1 & $\begin{array}{l}\text { Sargassum muticum } \\
\text { (brown seaweed) }\end{array}$ & $\begin{array}{l}\text { Freeze-dried } \\
\text { powder }\end{array}$ & $\begin{array}{l}\mathrm{FeCl}_{3} \cdot 6 \mathrm{H}_{2} \mathrm{O} \\
(0.1 \mathrm{M})\end{array}$ & $18 \pm 4 \mathrm{~nm}$ & Cubic & $\begin{array}{l}\text { Superparamagnetic } \\
\left(\mathrm{M}_{\mathrm{S}} 22.1 \mathrm{emu} / \mathrm{g}\right)\end{array}$ & - & $\begin{array}{l}\text { Mahdavi et al } \\
\text { (2013) }\end{array}$ \\
\hline 2 & $\begin{array}{l}\text { Kappaphycus alvarezii (red } \\
\text { seaweed) }\end{array}$ & $\begin{array}{l}\text { Dried, grinded } \\
\text { powder }\end{array}$ & $\begin{array}{l}\mathrm{FeCl}_{2} \cdot 4 \mathrm{H}_{2} \mathrm{O} \\
\mathrm{FeCl}_{3} \cdot 6 \mathrm{H}_{2} \mathrm{O} \\
\mathrm{NaOH}(1 \mathrm{M})\end{array}$ & $14.7 \mathrm{~nm}$ & Spherical & - & - & $\begin{array}{l}\text { Yew et al. } \\
(2016)\end{array}$ \\
\hline 3 & $\begin{array}{l}\text { Chaetomorphaantennina } \\
\text { (green algae) }\end{array}$ & Cell free extract & $\begin{array}{l}\mathrm{FeCl}_{2} \cdot 4 \mathrm{H}_{2} \mathrm{O} \\
\mathrm{NaOH}\end{array}$ & $9-10 \mathrm{~nm}$ & - & Ferromagnetic & - & $\begin{array}{l}\text { Siji et al. } \\
(2018)\end{array}$ \\
\hline 4 & $\begin{array}{l}\text { Turbinriaturbinata (brown } \\
\text { algae) }\end{array}$ & Cell free extract & $\begin{array}{l}\mathrm{FeCl}_{2} \cdot 4 \mathrm{H}_{2} \mathrm{O} \\
\mathrm{NaOH}\end{array}$ & $8-14 \mathrm{~nm}$ & - & Ferromagnetic & - & $\begin{array}{l}\text { Siji et al. } \\
(2018)\end{array}$ \\
\hline 5 & $\begin{array}{l}\text { Pterocladia capillacea (red } \\
\text { seaweed) }\end{array}$ & Dried powder & $\mathrm{FeCl}_{3}(0.1 \mathrm{M})$ & $16.85-22.47 \mathrm{~nm}$ & Nanosphere & - & $\begin{array}{l}\text { Antimicrobial, } \\
\text { antifungal }\end{array}$ & $\begin{array}{l}\text { Salem et al. } \\
(2019)\end{array}$ \\
\hline 6 & $\begin{array}{l}\text { Colpomenia sinuosa (brown } \\
\text { seaweed) }\end{array}$ & Dried powder & $\mathrm{FeCl}_{3}(0.1 \mathrm{M})$ & $11.24-33.71 \mathrm{~nm}$ & Nanosphere & - & $\begin{array}{l}\text { Antimicrobial, } \\
\text { antifungal }\end{array}$ & $\begin{array}{l}\text { Salem et al. } \\
(2019)\end{array}$ \\
\hline
\end{tabular}

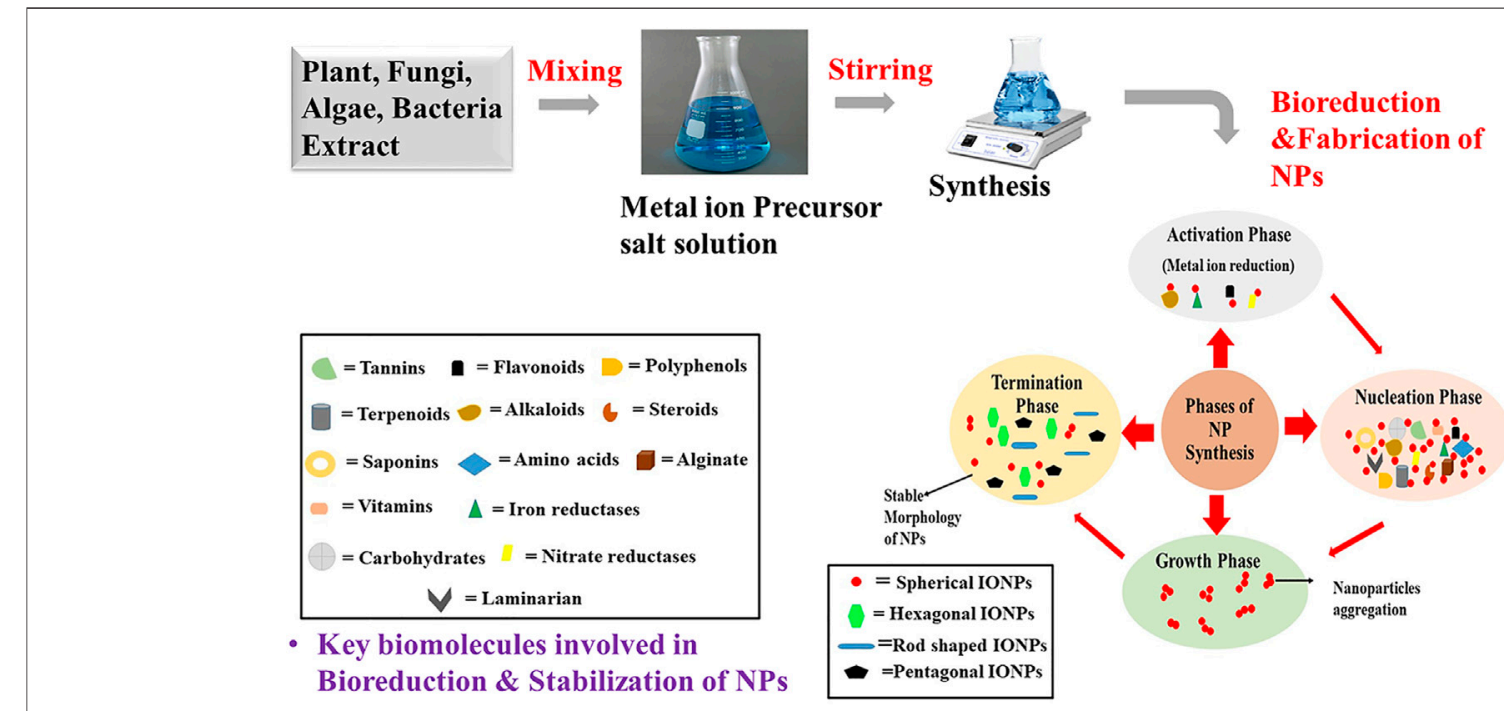

FIGURE 4 | Schematic representation of the mechanism of synthesis of metal oxide NPs by using plants, algae, fungi and bacteria.

metal nanoparticles, work as chelating and capping agents. Nextly in the growth phase complete reduction of metal ion occur from monovalent or divalent oxidation state to zero valent oxidation states. In this growth progression stage, metallic nanoparticles aggregate among themselves to attain different morphology. Finally, in the termination phase final stable morphology of nanoparticles are obtained and are capped by biomolecules so that steric repulsion among them increases which is thought to reduces the problem of agglomeration (Gan et al., 2012; Akhtar et al., 2013; Jeevanandam et al., 2016; Ishak et al., 2019). Typically, Iron oxide nanoparticles synthesized by chemical and physical routes are extremely reactive in nature and can easily undergo oxidation by atmospheric oxygen to agglomerate together. In addition to this, in order to minimize surface energy arising because of the high surface-area-to volume ratio, nanoparticles usually tend to aggregate. Varity of stabilizers are added in the chemical and physical synthesis procedure to prevent agglomeration of the synthesized nanoparticles. No such stabilizing agents are required in biological synthesis methods as biomolecules present in the extract act as capping agents and stabilized the synthesized nanoparticles (Gudikandula and Maringanti, 2016). From the biomedical application point of view, the size of iron oxide nanoparticles should be less than $20 \mathrm{~nm}$, they must be uncapped, should posses good magnetic properties and have critical transition temperature (Tc). In the green synthesis approach, different reaction parameters like temperature, $\mathrm{pH}$, stirring, metal salt concentration and volume of extract are very crucial to obtained nanoparticles of proper shape, size, crystallinity, purity, stability and morphology. In plants mediated nanoparticle synthesis, choice of the starting material is very important. Each part of the plant varies in the concentration of reducing agents like flavones, terpenoids, sugars, 
ketones, amides, anthracenes, alkaloids. Leaf extract is considered as the best source for the synthesis of metal oxide nanoparticles as it contains high concentration of phytochemicals that helps in bioreduction of metal ions. Out of bacteria and fungi, fungi is considered as an excellent source for the synthesis of metal oxide nanoparticles. The main reason for its wide usage is its capability to secrete large amount of enzymes and withstand flow pressure and agitation (Gudikandulaand Maringanti, 2016; Singh et al., 2018; Ajinkya et al., 2020).

\section{DISCUSSION}

Biocompatible synthesis of nanoparticles is the centralized area of the study in the field of nanotechnology. Green sources are the main players in the biological synthesis of iron oxide nanoparticles due to the presence of wide variety of biomolecules showing strong reduction of metal ions to form nanoparticles from the bulk metal. There are number of reasons which make biological synthesis of nanoparticles very lucrative. First of all, this emerges as an inexpensive approach as simple physical conditions are required for the synthesis, no requirement of sophisticated instruments, and because of the wide availability of the biological agents employed. Next point which is worthy to consider is the absence of toxic chemicals required for the synthesis which make these particles biocompatible and environment friendly. Moreover, water is the key solvent employed in most of the green synthesis approaches adding additional meaning to the green technology. Lastly, no separate capping agents are required

\section{REFERENCES}

Abdeen, M., Sabry, S., Ghozlan, H., El-Gendy, A. A., and Carpenter, E. E. (2016). Microbial-physical Synthesis of Fe and Fe3O4 Magnetic Nanoparticles Using Aspergillus niger YESM1 and Supercritical Condition of Ethanol. J. Nanomater. 2016, 1-7. doi:10.1155/2016/9174891

Abdullah, J. A. A., Eddine, L. S., Abderrhmane, B., Alonso-González, M., Guerrero, A., and Romero, A. (2020). Green Synthesis and Characterization of Iron Oxide Nanoparticles by Pheonix Dactylifera Leaf Extract and Evaluation of Their Antioxidant Activity. Sust. Chem. Pharm. 17, 100280. doi:10.1016/j.scp.2020. 100280

Adelere, I. A., and Lateef, A. (2016). A Novel Approach to the green Synthesis of Metallic Nanoparticles: the Use of Agro-Wastes, Enzymes, and Pigments. Nanotechnology Rev. 5 (6), 567-587. doi:10.1515/ntrev-2016-0024

Agarwal, H., Kumar, S. V., and Rajeshkumar, S. (2017). A Review on green Synthesis of Zinc Oxide Nanoparticles-An Eco-Friendly Approach. ResourceEfficient Tech. 3 (4), 406-413. doi:10.1016/j.reffit.2017.03.002

Ajinkya, N., Yu, X., Kaithal, P., Luo, H., Somani, P., and Ramakrishna, S. (2020). Magnetic Iron Oxide Nanoparticle (IONP) Synthesis to Applications: Present and Future. Materials 13 (20), 4644. doi:10.3390/ma13204644

Akhtar, M. S., Panwar, J., and Yun, Y. S. (2013). Biogenic Synthesis of Metallic Nanoparticles by Plant Extracts. ACS Sust. Chem. and Eng. 1 (6), 591-602. doi:10.1021/sc300118u

Akhter, S. M. H., Mohammad, F., and Ahmad, S. (2019). Terminalia Belerica Mediated green Synthesis of Nanoparticles of Copper, Iron and Zinc Metal Oxides as the Alternate Antibacterial Agents against Some Common Pathogens. BioNanoScience 9 (2), 365-372. doi:10.1007/s12668-019-0601-4

Alam, H., Khatoon, N., Khan, M. A., Husain, S. A., Saravanan, M., and Sardar, M. (2020). Synthesis of Selenium Nanoparticles Using Probiotic Bacteria for the stabilization of the biologically synthesized nanoparticles as the biomolecules present in the extract are self -sufficient to carry out this action, so no agglomeration is encountered. However, the biggest challenge for this approach is the reproducibility of this method. Such method presents a passive approach toward the synthesis of the nanoparticles where the reactants are utilized passively and partially. The unreacted components can lead to the formation of undesired products with varied properties making the method nonreproducible. The immediate recovery of the product can solve the problem to certain extent but it is still a challenge for the researchers working with this green synthesis. Researchers are required to focus on the size controlled synthesis of the nanoparticles as size is the key factor deciding the properties and thus utility of the nanoparticles. Further, compilation of current work proves that so far numerous queries about the parameters controlling size, shape, crystallinity, yield of the nanoparticles produced and precise magnetic properties of the nanoparticles synthesized using green approach are still not explained. Hence, further research in these directions is exceedingly necessary to fill these lacunas and come up with more controlled studies.

\section{AUTHOR CONTRIBUTIONS}

$\mathrm{P}, \mathrm{N}$, and AS designed, wrote the manuscript, revised and finalized the draft. KK supervised the whole project and reviewed the manuscript. All authors contributed to the article and approved the submitted version.

Lactobacillus Acidophilus and Their Enhanced Antimicrobial Activity against Resistant Bacteria. J. Cluster Sci. 31 (5), 1003-1011. doi:10.1007/ s10876-019-01705-6

Alkhattaf, F. S. (2021). Gold and Silver Nanoparticles: green Synthesis, Microbes, Mechanism, Factors, Plant Disease Management and Environmentalrisks. Saudi J. Biol. Sci. 28 (6), 3624-3631. doi:10.1016/j.sjbs.2021.03.078

Aminabad, N. S., Farshbaf, M., and Akbarzadeh, A. (2019). Recent Advances of Gold Nanoparticles in Biomedical Applications: State of the Art. Cel Biochem. Biophys. 77 (2), 123-137. doi:10.1007/s12013-018-0863-4

Amoabediny, G., Haghiralsadat, F., Naderinezhad, S., Helder, M. N., Akhoundi Kharanaghi, E., Mohammadnejad Arough, J., et al. (2018). Overview of Preparation Methods of Polymeric and Lipid-Based (Niosome, Solid Lipid, Liposome) Nanoparticles: A Comprehensive Review. Int. J. Polymeric Mater. Polymeric Biomater. 67 (6), 383-400. doi:10.1080/ 00914037.2017 .1332623

Arularasu, M. V., Devakumar, J., and Rajendran, T. V. (2018). An Innovative Approach for green Synthesis of Iron Oxide Nanoparticles: Characterization and its Photocatalytic Activity. Polyhedron 156, 279-290. doi:10.1016/j.poly. 2018.09.036

Arya, A., Mishra, V., and Chundawat, T. S. (2019). Green Synthesis of Silver Nanoparticles from green Algae (Botryococcus Braunii) and its Catalytic Behavior for the Synthesis of Benzimidazoles. Chem. Data Collections 20, 100190. doi:10.1016/j.cdc.2019.100190

Asghar, M. A., Zahir, E., Asghar, M. A., Iqbal, J., and Rehman, A. A. (2020). Facile, One-Pot Biosynthesis and Characterization of Iron, Copper and Silver Nanoparticles Using Syzygium Cumini Leaf Extract: As an Effective Antimicrobial and Aflatoxin B1 Adsorption Agents. PloS one 15 (7), e0234964. doi:10.1371/journal.pone.0234964

Aziz, N., Faraz, M., Pandey, R., Shakir, M., Fatma, T., Varma, A., et al. (2015). Facile Algae-Derived Route to Biogenic Silver Nanoparticles: Synthesis, Antibacterial, 
and Photocatalytic Properties. Langmuir 31 (42), 11605-11612. doi:10.1021/ acs.langmuir.5b03081

Beheshtkhoo, N., Kouhbanani, M. A. J., Savardashtaki, A., Amani, A. M., and Taghizadeh, S. (2018). Green Synthesis of Iron Oxide Nanoparticles by Aqueous Leaf Extract of Daphne Mezereum as a Novel Dye Removing Material. Appl. Phys. A 124 (5), 363. doi:10.1007/s00339-018-1782-3

Beveridge, T. J., Hughes, M. N., Lee, H., Leung, K. T., Poole, R. K., Savvaidis, I., et al. (1996). Metal-microbe Interactions: Contemporary Approaches. Adv. Microb. Physiol. 38, 177-243. doi:10.1016/S0065-2911(08)60158-7

Bharde, A., Rautaray, D., Bansal, V., Ahmad, A., Sarkar, I., Yusuf, S. M., et al. (2006). Extracellular Biosynthesis of Magnetite Using Fungi. Small 2 (1), 135-141. doi:10.1002/smll.200500180

Bhargava, A., Jain, N., Barathi, M., Akhtar, M. S., Yun, Y. S., and Panwar, J. (2013). Synthesis, Characterization and Mechanistic Insights of Mycogenic Iron Oxide Nanoparticles. Nanotechnology Sustain. Dev. 15, 337-348. doi:10.1007/978-3319-05041-6_27

Bhatia, S. (2016). Nanoparticles Types, Classification, Characterization, Fabrication Methods and Drug Delivery Applications. Nat. Polym. Drug Deliv. Syst., 33-93. doi:10.1007/978-3-319-41129-3_2

Bhuiyan, M. S. H., Miah, M. Y., Paul, S. C., Aka, T. D., Saha, O., Rahaman, M. M., et al. (2020). Green Synthesis of Iron Oxide Nanoparticle Using Carica Papaya Leaf Extract: Application for Photocatalytic Degradation of Remazol Yellow RR Dye and Antibacterial Activity. Heliyon 6 (8), e04603. doi:10.1016/j.heliyon. 2020.e04603

Bibi, I., Nazar, N., Ata, S., Sultan, M., Ali, A., Abbas, A., et al. (2019). Green Synthesis of Iron Oxide Nanoparticles Using Pomegranate Seeds Extract and Photocatalytic Activity Evaluation for the Degradation of Textile Dye. J. Mater. Res. Technol. 8 (6), 6115-6124. doi:10.1016/j.jmrt.2019.10.006

Borah, D., Das, N., Das, N., Bhattacharjee, A., Sarmah, P., Ghosh, K., et al. (2020). Alga Mediated Facile green Synthesis of Silver Nanoparticles: Photophysical, Catalytic and Antibacterial Activity. Appl. Organomet. Chem. 34 (5), e5597. doi:10.1002/aoc.5597

Campos, E. A., Pinto, D. V. B. S., Oliveira, J. I. S. D., Mattos, E. D. C., and Dutra, R. D. C. L. (2015). Synthesis, Characterization and Applications of Iron Oxide Nanoparticles-A Short Review. J. Aerospace Technol. Manag. 7 (3), 267-276. doi:10.5028/jatm.v7i3.471

Chapot-Chartier, M. P., and Kulakauskas, S. (2014). Cell wall Structure and Function in Lactic Acid Bacteria. Microb. Cel. factories 13 (S1), S9. doi:10. 1186/1475-2859-13-S1-S9

Chatterjee, S., Mahanty, S., Das, P., Chaudhuri, P., and Das, S. (2020). Biofabrication of Iron Oxide Nanoparticles Using Manglicolous Fungus Aspergillus niger BSC-1 and Removal of Cr (VI) from Aqueous Solution. Chem. Eng. J. 385, 123790. doi:10.1016/j.cej.2019.123790

Chauhan, S., and Upadhyay, L. S. B. (2019). Biosynthesis of Iron Oxide Nanoparticles Using Plant Derivatives of Lawsonia Inermis (Henna) and its Surface Modification for Biomedical Application. Nanotechnology Environ. Eng. 4 (1), 8. doi:10.1007/s41204-019-0055-5

Chen, S., Yuan, R., Chai, Y., and Hu, F. (2013). Electrochemical Sensing of Hydrogen Peroxide Using Metal Nanoparticles: a Review. Microchimica Acta 180 (1), 15-32. doi:10.1007/s00604-012-0904-4

Devi, H. S., Boda, M. A., Shah, M. A., Parveen, S., and Wani, A. H. (2019). Green Synthesis of Iron Oxide Nanoparticles Using Platanus Orientalis Leaf Extract for Antifungal Activity. Green. Process. Synth. 8 (1), 38-45. doi:10.1515/gps2017-0145

Ealias, A. M., and Saravanakumar, M. P. (2017). A Review on the Classification, Characterisation, Synthesis of Nanoparticles and Their Application. IOP Conf. Ser. Mater. Sci. Eng. 263, 032019. doi:10.1088/1757-899X/263/3/032019

Fang, X., Wang, Y., Wang, Z., Jiang, Z., and Dong, M. (2019). Microorganism Assisted Synthesized Nanoparticles for Catalytic Applications. Energies 12 (1), 190. doi:10.3390/en12010190

Fani, M., Ghandehari, F., and Rezaee, M. (2018). Biosynthesis of Iron Oxide Nanoparticles by Cytoplasmic Extract of Bacteria Lactobacillus Fermentum. J. Med. Chem. Sci. 1 (2), 28-30. doi:10.26655/jmchemsci.2018.9.2

Fariq, A., Khan, T., and Yasmin, A. (2017). Microbial Synthesis of Nanoparticles and Their Potential Applications in Biomedicine. J. Appl. Biomed. 15 (4), 241-248. doi:10.1016/j.jab.2017.03.004

Fatemi, M., Mollania, N., Momeni-Moghaddam, M., and Sadeghifar, F. (2018). Extracellular Biosynthesis of Magnetic Iron Oxide Nanoparticles by Bacillus
Cereus Strain HMH1: Characterization and In Vitro Cytotoxicity Analysis on MCF-7 and 3T3 Cell Lines. J. Biotechnol. 270, 1-11. doi:10.1016/j.jbiotec.2018. 01.021

Gahlawat, G., and Choudhury, A. R. (2019). A Review on the Biosynthesis of Metal and Metal Salt Nanoparticles by Microbes. RSC Adv. 9 (23), 12944-12967. doi:10.1039/C8RA10483B

Gan, P. P., and Li, S. F. Y. (2012). Potential of Plant as a Biological Factory to Synthesize Gold and Silver Nanoparticles and Their Applications. Rev. Environ. Sci. Bio/Technology 11 (2), 169-206. doi:10.1007/s11157-012-9278-7

Gao, L., Fan, K., and Yan, X. (2020). Iron Oxide Nanozyme: A Multifunctional Enzyme Mimetics for Biomedical Application. Nanozymology, 105-140. doi:10. 1007/978-981-15-1490-6_5

Garg, D., Sarkar, A., Chand, P., Bansal, P., Gola, D., Sharma, S., et al. (2020). Synthesis of Silver Nanoparticles Utilizing Various Biological Systems: Mechanisms and Applications-A Review. Prog. Biomater. 9 (3), 1-15. doi:10.1007/s40204-020-00135-2

Gericke, M., and Pinches, A. (2006). Biological Synthesis of Metal Nanoparticles. Hydrometallurgy 83 (1-4), 132-140. doi:10.1016/j.hydromet.2006.03.019

Ghaffari-Moghaddam, M., Hadi-Dabanlou, R., Khajeh, M., Rakhshanipour, M., and Shameli, K. (2014). Green Synthesis of Silver Nanoparticles Using Plant Extracts. Korean J. Chem. Eng. 31 (4), 548-557. doi:10.1007/s11814-0140014-6

Gholampoor, N., Emtiazi, G., and Emami, Z. (2015). The Influence of Microbacterium Hominis and Bacillus Licheniformis Extracellular Polymers on Silver and Iron Oxide Nanoparticles Production; green Biosynthesis and Mechanism of Bacterial Nano Production. J. Nanomater. Mol. Nanotechnol 04 (02). doi:10.4172/2324-8777.1000160

Grasso, G., Zane, D., and Dragone, R. (2020). Microbial Nanotechnology: Challenges and Prospects for green Biocatalytic Synthesis of Nanoscale Materials for Sensoristic and Biomedical Applications. Nanomaterials 10 (1), 11. doi:10.3390/nano10010011

Gudikandula, K., and Charya Maringanti, S. (2016). Synthesis of Silver Nanoparticles by Chemical and Biological Methods and Their Antimicrobial Properties. J. Exp. Nanoscience 11 (9), 714-721. doi:10.1080/17458080.2016.1139196

Guilger-Casagrande, M., and de Lima, R. (2019). Synthesis of Silver Nanoparticles Mediated by Fungi: A Review. Front. Bioeng. Biotechnol. 7, 287. doi:10.3389/ fbioe.2019.00287

Hernández-Hernández, A. A., Aguirre-Álvarez, G., Cariño-Cortés, R., MendozaHuizar, L. H., and Jiménez-Alvarado, R. (2020). Iron Oxide Nanoparticles: Synthesis, Functionalization, and Applications in Diagnosis and Treatment of Cancer. Chem. Pap. 74 (11), 3809-3824. doi:10.1007/s11696-020-01229-8

Hooda, R., and Sharma, M. (2020). GREEN SYNTHESIS, CHARACTERIZATION AND ANTIBACTERIAL ACTIVITY OF IRON OXIDE NANOPARTICLES. Plant Arch. 20 (1), 1196-1200.

Hulkoti, N. I., and Taranath, T. C. (2014). Biosynthesis of Nanoparticles Using Microbes-A Review. Colloids Surf. B: Biointerfaces 121, 474-483. doi:10.1016/ j.colsurfb.2014.05.027

Hussain, M., Raja, N. I., Iqbal, M., and Aslam, S. (2019). Applications of Plant Flavonoids in the green Synthesis of Colloidal Silver Nanoparticles and Impacts on Human Health. Iranian J. Sci. Technol. Trans. A: Sci. 43 (3), 1381-1392. doi:10.1007/s40995-017-0431-6

Iravani, S., and Varma, R. S. (2020). Bacteria in Heavy Metal Remediation and Nanoparticle Biosynthesis. ACS Sust. Chem. andEng. 8 (14), 5395-5409. doi:10. 1021/acssuschemeng.0c00292

Ishak, N. M., Kamarudin, S. K., and Timmiati, S. N. (2019). Green Synthesis of Metal and Metal Oxide Nanoparticles via Plant Extracts: an Overview. Mater. Res. Express 6 (11), 112004. doi:10.1088/2053-1591/ab4458

Izadiyan, Z., Shameli, K., Miyake, M., Hara, H., Mohamad, S. E. B., Kalantari, K., et al. (2020). Cytotoxicity Assay of Plant-Mediated Synthesized Iron Oxide Nanoparticles Using Juglans Regia green Husk Extract. Arabian J. Chem. 13 (1), 2011-2023. doi:10.1016/j.arabjc.2018.02.019

Jacinto, M. J., Silva, V. C., Valladão, D. M. S., and Souto, R. S. (2020). Biosynthesis of Magnetic Iron Oxide Nanoparticles: a Review. Biotechnol. Lett. 43 (1), 1-12. doi:10.1007/s10529-020-03047-0(0123456789

Jamzad, M., and Bidkorpeh, M. K. (2020). Green Synthesis of Iron Oxide Nanoparticles by the Aqueous Extract of Laurus Nobilis L. Leaves and Evaluation of the Antimicrobial Activity. J. Nanostructure Chem. 10 (3), 193-201. doi:10.1007/s40097-020-00341-1 
Javaid, A., Oloketuyi, S. F., Khan, M. M., and Khan, F. (2018). Diversity of Bacterial Synthesis of Silver Nanoparticles. BioNanoScience 8 (1), 43-59. doi:10.1007/ s12668-017-0496-x

Jeevanandam, J., Chan, Y. S., and Danquah, M. K. (2016). Biosynthesis of Metal and Metal Oxide Nanoparticles. ChemBioEng Rev. 3 (2), 55-67. doi:10.1002/ cben. 201500018

Jubran, A. S., Al-Zamely, O. M., and Al-Ammar, M. H. (2020). A Study of Iron Oxide Nanoparticles Synthesis by Using Bacteria. Int. J. Pharm. Qual. Assur. 11 (01), 01-08.

Kanagasubbulakshmi, S., and Kadirvelu, K. (2017). Green Synthesis of Iron Oxide Nanoparticles Using Lagenaria Siceraria and Evaluation of its Antimicrobial Activity. Defence Life Sci. J. 2 (4), 422-427. doi:10.14429/dlsj.2.12277

Karade, V. C., Parit, S. B., Dawkar, V. V., Devan, R. S., Choudhary, R. J., Kedge, V. V., et al. (2019). A green Approach for the Synthesis of $\alpha$-Fe2O3 Nanoparticles from Gardenia Resinifera Plant and It's In Vitro Hyperthermia Application. Heliyon 5 (7), e02044. doi:10.1016/j.heliyon.2019.e02044

Karpagavinayagam, P., and Vedhi, C. (2019). Green Synthesis of Iron Oxide Nanoparticles Using Avicennia marina Flower Extract. Vacuum 160, 286-292. doi:10.1016/j.vacuum.2018.11.043

Kaul, R., Kumar, P., Burman, U., Joshi, P., Agrawal, A., Raliya, R., et al. (2012). Magnesium and Iron Nanoparticles Production Using Microorganisms and Various Salts. Mater. Science-Poland 30 (3), 254-258. doi:10.2478/s13536-0120028-x

Khalil, A. T., Ovais, M., Ullah, I., Ali, M., Shinwari, Z. K., and Maaza, M. (2017). Biosynthesis of Iron Oxide (Fe2O3) Nanoparticles via Aqueous Extracts of Sageretia Thea (Osbeck.) and Their Pharmacognostic Properties. Green. Chem. Lett. Rev. 10 (4), 186-201. doi:10.1080/17518253.2017.1339831

Khan, A. U., Khan, M., Malik, N., Cho, M. H., and Khan, M. M. (2019a). Recent Progress of Algae and Blue-green Algae-Assisted Synthesis of Gold Nanoparticles for Various Applications. Bioproc. Biosyst. Eng. 42 (1), 1-15. doi:10.1007/s00449-018-2012-2

Khan, I., Saeed, K., and Khan, I. (2019b). Nanoparticles: Properties, Applications and Toxicities. Arabian J. Chem. 12 (7), 908-931. doi:10.1016/j.arabjc.2017. 05.011

Król, A., Railean-Plugaru, V., Pomastowski, P., Złoch, M., and Buszewski, B. (2018). Mechanism Study of Intracellular Zinc Oxide Nanocomposites Formation. Colloids Surf. A: Physicochemical Eng. Aspects 553, 349-358. doi:10.1016/j.colsurfa.2018.05.069

Kulkarni, N., and Muddapur, U. (2014). Biosynthesis of Metal Nanoparticles: a Review. J. Nanotechnology 2014, 1-8. doi:10.1155/2014/510246

Kumar, H., Venkatesh, N., Bhowmik, H., and Kuila, A. (2018). Metallic Nanoparticle: a Review. Biomed. J. Scientific andTech. Res. 4 (2), 3765-3775. doi:10.26717/BJSTR.2018.04.001011

Kumar, S. A., Abyaneh, M. K., Gosavi, S. W., Kulkarni, S. K., Pasricha, R., Ahmad, A., et al. (2007). Nitrate Reductase-Mediated Synthesis of Silver Nanoparticles from AgNO 3. Biotechnol. Lett. 29 (3), 439-445. doi:10.1007/s10529-0069256-7

Latif, M. S., Abbas, S., Kormin, F., and Mustafa, M. K. (2019). Green Synthesis of Plant-Mediated Metal Nanoparticles: The Role of Polyphenols. Asian J. Pharmaceut. Clin. Res. 12 (7), 75-84. doi:10.22159/ajpcr.2019.v12i7.33211

Laurent, S., Forge, D., Port, M., Roch, A., Robic, C., Vander Elst, L., et al. (2008). Magnetic Iron Oxide Nanoparticles: Synthesis, Stabilization, Vectorization, Physicochemical Characterizations, and Biological Applications. Chem. Rev. 108 (6), 2064-2110. doi:10.1021/cr068445e

Li, X. Q., and Zhang, W. X. (2006). Iron Nanoparticles: The Core- Shell Structure and Unique Properties for Ni (II) Sequestration. Langmuir 22 (10), 4638-4642. doi:10.1021/la060057k

Lohrasbi, S., Kouhbanani, M. A. J., Beheshtkhoo, N., Ghasemi, Y., Amani, A. M., and Taghizadeh, S. (2019). Green Synthesis of Iron Nanoparticles Using Plantago Major Leaf Extract and Their Application as a Catalyst for the Decolorization of Azo Dye. BioNanoScience 9 (2), 317-322. doi:10.1007/ s12668-019-0596-x

Madubuonu, N., Aisida, S. O., Ahmad, I., Botha, S., Zhao, T. K., Maaza, M., et al. (2020). Bio-inspired Iron Oxide Nanoparticles Using Psidium Guajava Aqueous Extract for Antibacterial Activity. Appl. Phys. A 126 (1), 1-8. doi:10.1007/s00339-019-3249-6

Mahanty, S., Bakshi, M., Ghosh, S., Chatterjee, S., Bhattacharyya, S., Das, P., et al. (2019). Green Synthesis of Iron Oxide Nanoparticles Mediated by Filamentous
Fungi Isolated from Sundarban Mangrove Ecosystem, India. BioNanoScience 9 (3), 637-651. doi:10.1007/s12668-019-00644-w

Mahdavi, M., Namvar, F., Ahmad, M. B., and Mohamad, R. (2013). Green Biosynthesis and Characterization of Magnetic Iron Oxide (Fe3O4) Nanoparticles Using Seaweed (Sargassum Muticum) Aqueous Extract. Molecules 18 (5), 5954-5964. doi:10.3390/molecules 18055954

Majumder, A., Ramrakhiani, L., Mukherjee, D., Mishra, U., Halder, A., Mandal, A. K., et al. (2019). Green Synthesis of Iron Oxide Nanoparticles for Arsenic Remediation in Water and Sludge Utilization. Clean. Tech. Environ. Pol. 21 (4), 795-813. doi:10.1007/s10098-019-01669-1

Malakootian, M., Yaseri, M., and Faraji, M. (2019). Removal of Antibiotics from Aqueous Solutions by Nanoparticles: a Systematic Review and Meta-Analysis. Environ. Sci. Pollut. Res. 26 (9), 8444-8458. doi:10.1007/s11356-019-04227-w

Malhotra, N., Lee, J. S., Liman, R. A. D., Ruallo, J. M. S., Villaflores, O. B., Ger, T. R., et al. (2020). Potential Toxicity of Iron Oxide Magnetic Nanoparticles: A Review. Molecules 25 (14), 3159. doi:10.3390/molecules25143159

Massironi, A., Morelli, A., Grassi, L., Puppi, D., Braccini, S., Maisetta, G., et al. (2019). Ulvan as Novel Reducing and Stabilizing Agent from Renewable Algal Biomass: Application to green Synthesis of Silver Nanoparticles. Carbohydr. Polym. 203, 310-321. doi:10.1016/j.carbpol.2018.09.066

Mei, W., and Wu, Q. (2018). Applications of Metal Nanoparticles in Medicine/ metal Nanoparticles as Anticancer Agents. Metal Nanoparticles, 169-190. doi:10.1002/9783527807093.ch7

Mirza, A. U., Kareem, A., Nami, S. A., Khan, M. S., Rehman, S., Bhat, S. A., et al. (2018). Biogenic Synthesis of Iron Oxide Nanoparticles Using Agrewia Optiva and Prunus Persica Phyto Species: Characterization, Antibacterial and Antioxidant Activity. J. Photochem. Photobiol. B: Biol. 185, 262-274. doi:10. 1016/j.jphotobiol.2018.06.009

Mittal, A. K., Chisti, Y., and Banerjee, U. C. (2013). Synthesis of Metallic Nanoparticles Using Plant Extracts. Biotechnol. Adv. 31 (2), 346-356. doi:10. 1016/j.biotechadv.2013.01.003

Mohamed, Y. M., Azzam, A. M., Amin, B. H., and Safwat, N. A. (2015). Mycosynthesis of Iron Nanoparticles by Alternaria alternata and its Antibacterial Activity. Afr. J. Biotechnol. 14 (14), 1234-1241. doi:10.5897/ AJB2014.14286

Mondal, P., Anweshan, A., and Purkait, M. K. (2020). Green Synthesis and Environmental Application of Iron-Based Nanomaterials and Nanocomposite: A Review. Chemosphere 259, 127509. doi:10.1016/j. chemosphere.2020.127509

Mourdikoudis, S., Pallares, R. M., and Thanh, N. T. (2018). Characterization Techniques for Nanoparticles: Comparison and Complementarity upon Studying Nanoparticle Properties. Nanoscale 10 (27), 12871-12934. doi:10. 1039/C8NR02278J

Mughal, B., Zaidi, S. Z. J., Zhang, X., and Hassan, S. U. (2021). Biogenic Nanoparticles: Synthesis, Characterisation and Applications. Appl. Sci. 11 (6), 2598. doi:10.3390/app11062598

Nadeem, M., Tungmunnithum, D., Hano, C., Abbasi, B. H., Hashmi, S. S., Ahmad, W., et al. (2018). The Current Trends in the green Syntheses of Titanium Oxide Nanoparticles and Their Applications. Green. Chem. Lett. Rev. 11 (4), 492-502. doi:10.1080/17518253.2018.1538430

Narayanan, K. B., and Sakthivel, N. (2010). Biological Synthesis of Metal Nanoparticles by Microbes. Adv. Colloid Interf. Sci. 156 (1-2), 1-13. doi:10. 1016/j.cis.2010.02.001

Noruzi, M. (2015). Biosynthesis of Gold Nanoparticles Using Plant Extracts. Bioproc. Biosyst. Eng. 38 (1), 1-14. doi:10.1007/s00449-014-1251-0

Odularu, A. T. (2018). Metal Nanoparticles: thermal Decomposition, Biomedicinal Applications to Cancer Treatment, and Future Perspectives, Bioinorganic Chem. Appl., 2018:1-6. doi:10.1155/2018/9354708

Oskam, G. (2006). Metal Oxide Nanoparticles: Synthesis, Characterization and Application. J. sol-gel Sci. Technol. 37 (3), 161-164. doi:10.1007/s10971-0056621-2

Ovais, M., Khalil, A. T., Raza, A., Khan, M. A., Ahmad, I., Islam, N. U., et al. (2016). Green Synthesis of Silver Nanoparticles via Plant Extracts: Beginning a new era in Cancer Theranostics. Nanomedicine 12 (23), 3157-3177. doi:10.2217/nnm2016-0279

Pantidos, N., and Horsfall, L. E. (2014). Biological Synthesis of Metallic Nanoparticles by Bacteria, Fungi and Plants. J. Nanomedicine and Nanotechnology 5 (5), 1. doi:10.4172/2157-7439.1000233 
Patiño-Ruiz, D., Sánchez-Botero, L., Tejeda-Benitez, L., Hinestroza, J., and Herrera, A. (2020). Green Synthesis of Iron Oxide Nanoparticles Using Cymbopogon Citratus Extract and Sodium Carbonate Salt: Nanotoxicological Considerations for Potential Environmental Applications. Environ. Nanotechnology, Monit. and Manag. 14, 100377. doi:10.1016/j.enmm.2020.100377

Pavani, K. V., and Kumar, N. S. (2013). Adsorption of Iron and Synthesis of Iron Nanoparticles by Aspergillus Species Kvp 12. Am. J. Nanomater. 1 (2), 24-26. doi:10.12691/ajn-1-2

Periakaruppan, R., Chen, X., Thangaraj, K., Jeyaraj, A., Nguyen, H. H., Yu, Y., et al. (2020). Utilization of tea Resources with the Production of Superparamagnetic Biogenic Iron Oxide Nanoparticles and an Assessment of Their Antioxidant Activities. J. Clean. Prod. 278, 123962. doi:10.1016/j.jclepro.2020.123962

Prasad, K., and Jha, A. K. (2009). ZnO Nanoparticles: Synthesis and Adsorption Study. Nat. Sci. 1 (02), 129. doi:10.4236/ns.2009.12016

Punjabi, K., Mehta, S., Yedurkar, S., Jain, R., Mukherjee, S., Kale, A., et al. (2018). Extracellular Synthesis of Silver Nanoparticle by Pseudomonas Hibiscicola-Mechanistic Approach. Adv. Nano Res. 6 (1), 81. doi:10.12989/ anr.2018.6.1.081

Rajeshkumar, S., and Bharath, L. V. (2017). Mechanism of Plant-Mediated Synthesis of Silver Nanoparticles-A Review on Biomolecules Involved, Characterisation and Antibacterial Activity. Chemico-biological interactions 273, 219-227. doi:10.1016/j.cbi.2017.06.019

Rastar, A., Yazdanshenas, M. E., Rashidi, A., and Bidoki, S. M. (2013). Theoretical Review of Optical Properties of Nanoparticles. J. Engineered Fibers Fabrics 8 (2), 155892501300800211. doi:10.1177/155892501300800211

Rauwel, P., Küünal, S., Ferdov, S., and Rauwel, E. (2015). A Review on the green Synthesis of Silver Nanoparticles and Their Morphologies Studied via TEM. Adv. Mater. Sci. Eng. 2015, 1-9. doi:10.1155/2015/682749

Razack, S. A., Suresh, A., Sriram, S., Ramakrishnan, G., Sadanandham, S., Veerasamy, M., et al. (2020). Green Synthesis of Iron Oxide Nanoparticles Using Hibiscus Rosa-Sinensis for Fortifying Wheat Biscuits. SN Appl. Sci. 2 (5), 1-9. doi:10.1007/s42452-020-2477-x

Revati, K., and Pandey, B. D. (2011). Microbial Synthesis of Iron-Based Nanomaterials-A Review. Bull. Mater. Sci. 34 (2), 191-198. doi:10.1007/ s12034-011-0076-6

Rong, K., Wang, J., Zhang, Z., and Zhang, J. (2020). Green Synthesis of Iron Nanoparticles Using Korla Fragrant Pear Peel Extracts for the Removal of Aqueous Cr (VI). Ecol. Eng. 149, 105793. doi:10.1016/j.ecoleng.2020.105793

Roy, S., and Das, T. K. (2015). Plant Mediated green Synthesis of Silver Nanoparticles. A. Rev. Int. J. Plant Biol. Res 3 (3), 1044-1055.

Saif, S., Tahir, A., and Chen, Y. (2016). Green Synthesis of Iron Nanoparticles and Their Environmental Applications and Implications. Nanomaterials 6 (11), 209. doi:10.3390/nano6110209

Salam, H. A., Rajiv, P., Kamaraj, M., Jagadeeswaran, P., Gunalan, S., and Sivaraj, R. (2012). Plants: green Route for Nanoparticle Synthesis. Int. Res. J. Biol. Sci. 1 (5), 85-90.

Saleh, T. A., Fadillah, G., and Saputra, O. A. (2019). Nanoparticles as Components of Electrochemical Sensing Platforms for the Detection of Petroleum Pollutants: A Review. Trac Trends Anal. Chem. 118, 194-206. doi:10.1016/j.trac.2019. 05.045

Salem, D. M., Ismail, M. M., and Aly-Eldeen, M. A. (2019). Biogenic Synthesis and Antimicrobial Potency of Iron Oxide (Fe3O4) Nanoparticles Using Algae Harvested from the Mediterranean Sea, Egypt. Egypt. J. Aquat. Res. 45 (3), 197-204. doi:10.1016/j.ejar.2019.07.002

Saratale, R. G., Karuppusamy, I., Saratale, G. D., Pugazhendhi, A., Kumar, G., Park, Y., et al. (2018). A Comprehensive Review on green Nanomaterials Using Biological Systems: Recent Perception and Their Future Applications. Colloids Surf. B: Biointerfaces 170, 20-35. doi:10.1016/j.colsurfb.2018.05.045

Schröfel, A., Kratošová, G., Šafařík, I., Šafaříková, M., Raška, I., and Shor, L. M. (2014). Applications of Biosynthesized Metallic Nanoparticles-A Review. Acta Biomater. 10 (10), 4023-4042. doi:10.1016/j.actbio.2014.05.022

Senthilkumar, S. R., and Sivakumar, T. (2014). Green tea (Camellia Sinensis) Mediated Synthesis of Zinc Oxide ( $\mathrm{ZnO}$ ) Nanoparticles and Studies on Their Antimicrobial Activities. Int. J. Pharm. Pharm. Sci. 6 (6), 461-465.

Sharma, D., Kanchi, S., and Bisetty, K. (2019). Biogenic Synthesis of Nanoparticles: A Review. Arabian J. Chem. 12 (8), 3576-3600. doi:10.1016/j.arabjc.2015.11.002

Sharma, P., Kumari, S., Ghosh, D., Yadav, V., Vij, A., Rawat, P., et al. (2021). Capping Agent-Induced Variation of Physicochemical and Biological
Properties of a-Fe2O3 Nanoparticles. Mater. Chem. Phys. 258, 123899. doi:10.1016/j.matchemphys.2020.123899

Shnoudeh, A. J., Hamad, I., Abdo, R. W., Qadumii, L., Jaber, A. Y., Surchi, H. S., et al. (2019). Synthesis, Characterization, and Applications of Metal Nanoparticles. Biomater. Bionanotechnology, 527-612. doi:10.1016/B978-012-814427-5.00015-9

Siddiqi, K. S., and Husen, A. (2016). Fabrication of Metal Nanoparticles from Fungi and Metal Salts: Scope and Application. Nanoscale Res. Lett. 11 (1), 98. doi:10. 1186/s11671-016-1311-2

Siji, S., Njana, J., Amrita, P. J., and Vishnudasan, D. (2018). Biogenic Synthesis of Iron Oxide Nanoparticles from marine Algae. TKM Int. J. Multidisciplinary Res. 1 (1), 1-7.

Silva, L. P., Reis, I. G., and Bonatto, C. C. (2015). Green Synthesis of Metal Nanoparticles by Plants: Current Trends and Challenges. Green. Process. Nanotechnology, 259-275. doi:10.1007/978-3-319-15461-9_9

Singh, J., Dutta, T., Kim, K. H., Rawat, M., Samddar, P., and Kumar, P. (2018). 'Green'synthesis of Metals and Their Oxide Nanoparticles: Applications for Environmental Remediation. J. nanobiotechnology 16 (1), 84. doi:10.1186/ s12951-018-0408-4

Singh, P., Kim, Y. J., Zhang, D., and Yang, D. C. (2016). Biological Synthesis of Nanoparticles from Plants and Microorganisms. Trends Biotechnology 34 (7), 588-599. doi:10.1016/j.tibtech.2016.02.006

Srikar, S. K., Giri, D. D., Pal, D. B., Mishra, P. K., and Upadhyay, S. N. (2016). Green Synthesis of Silver Nanoparticles: a Review. Green. Sust. Chem. 6 (1), 34-56. doi:10.4236/gsc.2016.61004

Srivastava, S. K., and Constanti, M. (2012). Room Temperature Biogenic Synthesis of Multiple Nanoparticles (Ag, Pd, Fe, Rh, Ni, Ru, Pt, Co, and $\mathrm{Li}$ ) by Pseudomonas aeruginosa SM1. J. Nanoparticle Res. 14 (4), 831. doi:10.1007/ s11051-012-0831-7

Sruthi, P. D., Sahithya, C. S., Justin, C., SaiPriya, C., Bhavya, K. S., Senthilkumar, P., et al. (2019). Utilization of Chemically Synthesized Super Paramagnetic Iron Oxide Nanoparticles in Drug Delivery, Imaging and Heavy Metal Removal. J. Cluster Sci. 30 (1), 11-24. doi:10.1007/s10876-018-1454-7

Subramaniyam, V., Subashchandrabose, S. R., Ganeshkumar, V., Thavamani, P., Chen, Z., Naidu, R., et al. (2016). Cultivation of Chlorella on Brewery Wastewater and Nano-Particle Biosynthesis by its Biomass. Bioresour. Technol. 211, 698-703. doi:10.1016/j.biortech.2016.03.154

Sundaram, P. A., Augustine, R., and Kannan, M. (2012). Extracellular Biosynthesis of Iron Oxide Nanoparticles by Bacillus Subtilis Strains Isolated from Rhizosphere Soil. Biotechnol. Bioproc. Eng. 17 (4), 835-840. doi:10.1007/ s12257-011-0582-9

Tarafdar, J. C., and Raliya, R. (2013). Rapid, Low-Cost, and Ecofriendly Approach for Iron Nanoparticle Synthesis Using Aspergillus oryzae TFR9. J. Nanoparticles 2013, 1-4. doi:10.1155/2013/141274

Thakkar, K. N., Mhatre, S. S., and Parikh, R. Y. (2010). Biological Synthesis of Metallic Nanoparticles. Nanomedicine: nanotechnology, Biol. Med. 6 (2), 257-262. doi:10.1016/j.nano.2009.07.002

Ting, A. S. Y., and Chin, J. E. (2020). Biogenic Synthesis of Iron Nanoparticles from Apple Peel Extracts for Decolorization of Malachite Green Dye. Water Air Soil Pollut. 231, 278. doi:10.1007/s11270-020-04658-z

Tong, W., Hui, H., Shang, W., Zhang, Y., Tian, F., Ma, Q., et al. (2021). Highly Sensitive Magnetic Particle Imaging of Vulnerable Atherosclerotic Plaque With Active Myeloperoxidase-Targeted Nanoparticles. Theranostics 11 (2), 506. doi:10.7150/thno.49812

Torabian, P., Ghandehari, F., and Fatemi, M. (2018). Biosynthesis of Iron Oxide Nanoparticles by Cytoplasmic Extracts of Bacteria Lactobacillus Casei. Asian J. Green Chem. 2 (3171-280), 181-188. doi:10.22034/ajgc.2018.57914

Tsekhmistrenko, S., Bityutskii, V., Tsekhmistrenko, O., Horalskyi, L., Tymoshok, N., and Spivak, M. (2020). Bacterial Synthesis of Nanoparticles: A green Approach, Biosyst. Divers.28(1), 9-17. doi:10.15421/012002

Turan, N. B., Erkan, H. S., Engin, G. O., and Bilgili, M. S. (2019). Nanoparticles in the Aquatic Environment: Usage, Properties, Transformation and Toxicity-A Review. Process Saf. Environ. Prot. 130, 238-249. doi:10.1016/j.psep.2019.08.014

Vahidi, H., Barabadi, H., and Saravanan, M. (2020). Emerging Selenium Nanoparticles to Combat Cancer: a Systematic Review. J. Cluster Sci. 31 (2), 301-309. doi:10.1007/s10876-019-01671-z

Vasantharaj, S., Sathiyavimal, S., Senthilkumar, P., LewisOscar, F., and Pugazhendhi, A. (2019). Biosynthesis of Iron Oxide Nanoparticles Using Leaf Extract of Ruellia Tuberosa: Antimicrobial Properties and Their 
Applications in Photocatalytic Degradation. J. Photochem. Photobiol. B: Biol. 192, 74-82. doi:10.1016/j.jphotobiol.2018.12.025

Vijayaraghavan, K., and Ashokkumar, T. (2017). Plant-mediated Biosynthesis of Metallic Nanoparticles: a Review of Literature, Factors Affecting Synthesis, Characterization Techniques and Applications. J. Environ. Chem. Eng. 5 (5), 4866-4883. doi:10.1016/j.jece.2017.09.026

Vinci, G., and Rapa, M. (2019). Noble Metal Nanoparticles Applications: Recent Trends in Food Control. Bioengineering 6 (1), 10. doi:10.3390/bioengineering6010010

Wu, W., He, Q., and Jiang, C. (2008). Magnetic Iron Oxide Nanoparticles: Synthesis and Surface Functionalization Strategies. Nanoscale Res. Lett. 3 (11), 397. doi:10.1007/s11671-008-9174-9

Yew, Y. P., Shameli, K., Miyake, M., Kuwano, N., Khairudin, N. B. B. A., Mohamad, S. E. B., et al. (2016). Green Synthesis of Magnetite (Fe3O4) Nanoparticles Using Seaweed (Kappaphycus Alvarezii) Extract. Nanoscale Res. Lett. 11 (1), 1-7. doi:10.1186/s11671-016-1498-2

Yusof, H. M., Mohamad, R., and Zaidan, U. H. (2019). Microbial Synthesis of Zinc Oxide Nanoparticles and Their Potential Application as an Antimicrobial Agent and a Feed Supplement in Animal Industry: a Review. J. Anim. Sci. Biotechnol. 10 (1), 57. doi:10.1186/s40104-019-0368-z
Zhang, R., Zhou, Y., Yan, X., and Fan, K. (2019). Advances in Chiral Nanozymes: a Review. Microchimica Acta 186 (12), 782. doi:10.1007/ s00604-019-3922-7

Zununi Vahed, S., Fathi, N., Samiei, M., Maleki Dizaj, S., and Sharifi, S. (2019). Targeted Cancer Drug Delivery with Aptamer-Functionalized Polymeric Nanoparticles. J. Drug Target. 27 (3), 292-299. doi:10.1080/1061186X.2018. 1491978

Conflict of Interest: The authors declare that the research was conducted in the absence of any commercial or financial relationships that could be construed as a potential conflict of interest.

Copyright $\odot 2021$ Priya, Naveen, Kaur and Sidhu. This is an open-access article distributed under the terms of the Creative Commons Attribution License (CC BY). The use, distribution or reproduction in other forums is permitted, provided the original author(s) and the copyright owner(s) are credited and that the original publication in this journal is cited, in accordance with accepted academic practice. No use, distribution or reproduction is permitted which does not comply with these terms. 